\title{
Elaboration on the architecture of $\mathrm{pH}$-sensitive surface charge-adaptive micelles with enhanced penetration and bactericidal activity in biofilms
}

Rong Guo, Keke Li, Baocheng Tian, Changrong Wang, Xiangjun Chen, Xinyu Jiang, Huayu He and Wei Hong* (1)

\begin{abstract}
Background: Biofilm formation is one of the main reasons for persistent bacterial infections. Recently, $\mathrm{pH}$-sensitive copolymers have fascinated incredible attention to tackle biofilm-related infections. However, the proper incorporation of pH-sensitive segments in the polymer chains, which could significantly affect the biofilms targeting ability, has not been particularly investigated. Herein, we synthesized three types of $\mathrm{pH}$-sensitive copolymers based on poly ( $\beta$-amino ester) (PAE), poly (lactic-co-glycolic acid) (PLA) and polyethylene glycol (PEG), PAE-PLA-mPEG (A-L-E), PLAPAE-mPEG (L-A-E) and PLA-PEG-PAE (L-E-A) to address this issue.
\end{abstract}

Results: The three copolymers could self-assemble into micelles $\left(M_{A-L-E}, M_{L-A-E}\right.$ and $\left.M_{L-E-A}\right)$ in aqueous medium. Compared with $M_{A-L E}$ and $M_{L-A-E}$ placing the PAE at the distal PEG end of PLA-PEG to yield PLA-PEG-PAE $\left(M_{L-E-A}\right)$ was characterized with proper triggering $\mathrm{pH}$, fully biofilm penetration, and high cell membrane binding affinity. Further loaded with Triclosan (TCS), $\mathrm{M}_{\mathrm{LE}-\mathrm{A} A} / \mathrm{TCS}$ could efficiently kill the bacteria either in planktonic or biofilm mode. We reasoned that PAE segments would be preferentially placed near the surface and distant from the hydrophobic PLA segments. This would increase the magnitude of surface charge-switching capability, as the cationic PAE ${ }^{+}$would easily disassociate from the inner core without conquering the additional hydrophobic force arising from covalent linkage with PLA segments, and rapidly rise to the outermost layer of the micellar surface due to the relative hydrophilicity. This was significant in that it could enable the micelles immediately change its surface charge where localized acidity occurred, and efficiently bind themselves to the bacterial surface where they became hydrolyzed by bacterial lipases to stimulate release of encapsulated TCS even a relatively short residence time to prevent rapid wash-out. In vivo therapeutic performance of $\mathrm{M}_{\mathrm{LEE}-\mathrm{A}} / \mathrm{TCS}$ was evaluated on a classical biofilm infection model, implant-related biofilm infection. The result suggested that $\mathrm{M}_{\mathrm{LE}-\mathrm{A}} / \mathrm{TCS}$ was effective for the treatment of implant-related biofilm infection, which was proved by the efficient clearance of biofilm-contaminated catheters and the recovery of surrounding infected tissues.

Conclusions: In summary, elaboration on the architecture of $\mathrm{pH}$-sensitive copolymers was the first step to target biofilm. The $\mathrm{M}_{\mathrm{LE}-\mathrm{A}}$ structure may represent an interesting future direction in the treatment of biofilm-relevant infections associated with acidity.

\footnotetext{
*Correspondence: hongwei_sy@bzmc.edu.cn

†Rong Guo and Keke Li contributed equally to this work, and the first authors of this manuscript

School of Pharmacy, Shandong New Drug Loading and Release

Technology and Preparation Engineering Laboratory, Binzhou Medical

University, 346 Guanhai Road, Yantai 264003, People's Republic of China
}

(c) The Author(s) 2021. Open Access This article is licensed under a Creative Commons Attribution 4.0 International License, which permits use, sharing, adaptation, distribution and reproduction in any medium or format, as long as you give appropriate credit to the original author(s) and the source, provide a link to the Creative Commons licence, and indicate if changes were made. The images or other third party material in this article are included in the article's Creative Commons licence, unless indicated otherwise in a credit line to the material. If material is not included in the article's Creative Commons licence and your intended use is not permitted by statutory regulation or exceeds the permitted use, you will need to obtain permission directly from the copyright holder. To view a copy of this licence, visit http://creativecommons.org/licenses/by/4.0/. The Creative Commons Public Domain Dedication waiver (http://creativeco mmons.org/publicdomain/zero/1.0/) applies to the data made available in this article, unless otherwise stated in a credit line to the data. 
Keywords: Biofilm targeting, pH-sensitive copolymers, Distribution of pH-sensitive segments, Implant-related biofilm infection

\section{Introduction}

Biofilm accounts for more than $60 \%$ of human infections of microorganisms [1-4]. Shielded by the protective matrix of the extracellular polymeric substances (EPS) produced by the biofilms $[3,5]$, the microorganisms can withstand up to 1000 times effective dose of antimicrobial agents compared with planktonic microorganisms [6]. To target biofilmsassociated infections, treatments have been proposed in a variety of ways, such as inhibition and disruption of biofilm formation, improvement of the penetration ability of antimicrobial agents into the EPS matrix and so on [7].

In recent years, design of micelles has enabled potential strategies to overcome the resistance of biofilms to antibacterial drugs [8-11]. However, studies have shown that the anti-biofilm efficacy of plain micelles was greatly limited due to the lack of penetration and retention ability [12]. Cationic micelles have since been conducted to increase the electrostatic interaction with negative component in biofilm, and enhanced in vitro anti-biofilm activity has been observed [13-15]. Unfortunately, cationic micelles have a short half-life in vivo and may cause potential toxicity through non-specific binding [16]. To overcome these shortcomings, $\mathrm{pH}$-sensitive copolymers are introduced to construct $\mathrm{pH}$-sensitive surface charge-adaptive micelles (SCAMs), which have been proposed in the treatment of biofilm associated infections [17, 18]. It is well documented that sugar fermentation creates a relatively acidic environment for the biofilm $[19,20]$, which triggers the conversion of SCAMs from neutral at the physiological pH of 7.4 to cationic. Hence, the infection specific targeting can be achieved while non-specific interactions are minimized [21-23]. Shi et al. have developed SCAMs composed of two copolymers, poly( $\varepsilon$-caprolactone)-b-poly ( $\beta$-amino ester) (PCL-b-PAE) and poly(ethylene glycol)-bpoly ( $\varepsilon$-caprolactone) (PEG-b-PCL) [24]. The micelle surface becomes hydrophilic and positive at acidic conditions while remaining hydrophobic and negative at the physiological $\mathrm{pH}$, which enabled the SCAMs to permeate through and function in the biofilms. Another SCAMs based on poly(D,Llactic-co-glycolic acid)-b-poly (L-histidine)-b-poly-(ethylene glycol) (PLGA-PLH-PEG) was developed by Farokhzad et al. to enhance biofilm penetration [25]. They reasoned that by placing the PLH between the PLGA and PEG to yield the linear structure of PLGA-PLH-PEG could not only maximize the surface charge-switching capability at acidic $\mathrm{pH}$ but also improve micelles colloidal stability and circulation time at physiological $\mathrm{pH}$. These results indicated that how to incorporate the $\mathrm{pH}$-sensitive segments in the polymer chains greatly affected the charge-switching capability. Therefore, the architecture of $\mathrm{pH}$-sensitive copolymers should be rationally designed before using, which has been generally ignored in most studies.

Usually, a typical pH-sensitive copolymer consists of three types of segments, hydrophobic segments, hydrophilic segments and $\mathrm{pH}$-sensitive segments. The hydrophobic segments could form a solid inner core where drugs are loaded. The hydrophilic segments could enable the micelles escape from the rapid clearance by the mononuclear phagocytic system [12]. The $\mathrm{pH}$-sensitive segments are responsible for switching the surface charge when the $\mathrm{pH}$ changes to acidic at the infection site [17]. It is clear that essential for biofilm penetration are both stealth in the blood and avid bacterial binding upon arriving at the acidity-associated infection. Poly (ethylene glycol) (PEG) has been amply applied to provide stealth properties to materials, making them "invisible" to cells, as well as resistant to protein adsorption. However, a big disadvantage induced by the PEGylation, called "PEG dilemma" phenomenon, was that PEG also hampered the electrostatic interaction between cationic micelles and bacteria. Additionally, in order to maximize the surface chargeswitching capability, the $\mathrm{pH}$-sensitive segments would be preferentially placed near the micelles surface.

Herein, our interests focused on elaborating the pH-sensitive copolymers to minimize the nontarget interactions at physiologic $\mathrm{pH} 7.4$ and produce strong multivalent electrostatic-mediated binding at acidic $\mathrm{pH}$ for biofilm treatment. We prepared three types of $\mathrm{pH}$-sensitive copolymers with similar compositions but different distributions of $\mathrm{pH}$-sensitive segments in the chains, PLA-PAE-mPEG, PAE-PLA-mPEG and PLA-PEG-PAE. As shown in Fig. 1, three copolymers could self-assembly into micelles $M_{L-A-E}$, $\mathrm{M}_{\mathrm{A}-\mathrm{L}-\mathrm{E}}$ and $\mathrm{M}_{\mathrm{L}-\mathrm{E}-\mathrm{A}}$ with PEG as the stable shell, PLA as the hydrophobic core and $\mathrm{PAE}$ as the $\mathrm{pH}$-sensitive hydrophobic core moieties. The triggering $\mathrm{pH}$ (the $\mathrm{pH}$ at which a remarkable surface charge reversal occurs, $\mathrm{pH}_{\mathrm{t}}$ ) was firstly investigated. It is noteworthy that, both $\mathrm{M}_{\mathrm{L}-\mathrm{A}-\mathrm{E}}$ and $\mathrm{M}_{\mathrm{L}-\mathrm{E}-\mathrm{A}}$ could elaborately control charge switching under the biofilm environment, with the $\mathrm{pH}_{\mathrm{t}}$ of 5.5 and 6.0, respectively. On the contrary, the $\mathrm{pH}_{\mathrm{t}}$ of $\mathrm{M}_{\mathrm{A}-\mathrm{L}-\mathrm{E}}$ was 4.0 , which was much lower than biofilm environmental $\mathrm{pH}(\approx 5.5)$, and not suitable for targeting biofilm. Next, the pH-dependent physicochemical properties of $\mathrm{M}_{\mathrm{L}-\mathrm{A}-\mathrm{E}}$ and $\mathrm{M}_{\mathrm{L}-\mathrm{E}-\mathrm{A}}$ (including particle size and zeta potential, micelles-bacteria binding affinity, and biofilm penetration) were characterized. Further loaded with Triclosan (TCS), the antibacterial efficacy and biofilm eradication of $\mathrm{M}_{\mathrm{L}-\mathrm{A}-\mathrm{E}} / \mathrm{TCS}$ and $\mathrm{M}_{\mathrm{L}-\mathrm{E}-\mathrm{A}} / \mathrm{TCS}$ were also evaluated in vitro and in vivo to reveal the structure-function 


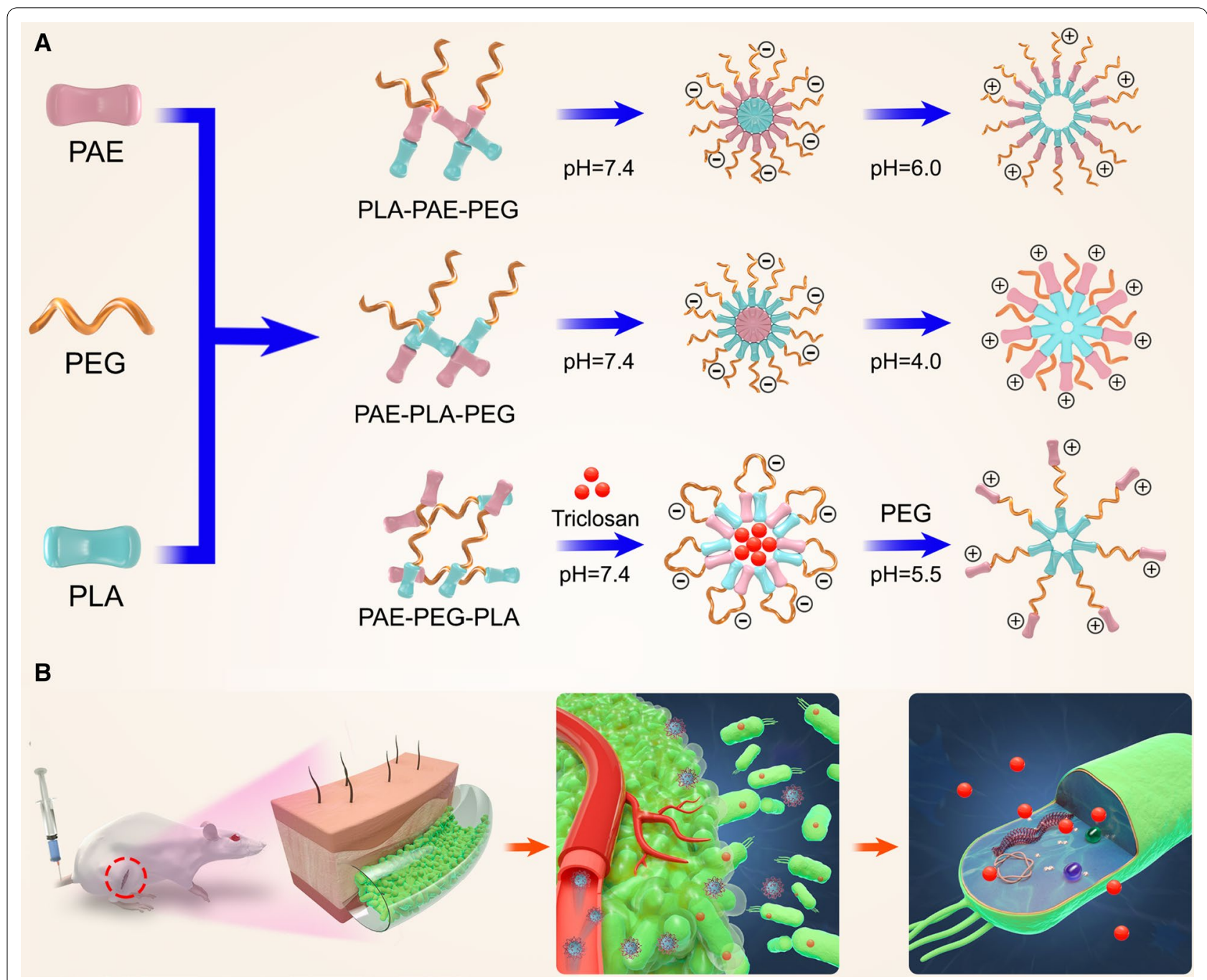

Fig. 1 Elaboration on the architecture of $\mathrm{pH}$-sensitive copolymers with proper $\mathrm{pH}_{\mathrm{t}}(\mathbf{a})$. The mechanism for targeting delivery of encapsulated drug into bacteria deep into biofilms using SCAMs for treatment of implant-related biofilm infections (b)

relationship of $\mathrm{pH}$-sensitive copolymers. Results demonstrated that $\mathrm{M}_{\mathrm{L}-\mathrm{E}-\mathrm{A}}$ promoted the effective penetration and long-term retention inside biofilms, and were more effective in killing bacteria deep into biofilm both in vitro and in vivo compared to free TCS or TCS encapsulated in $\mathrm{M}_{\mathrm{L}-\mathrm{A}-\mathrm{E}}$. This study may provide significant suggestion in designing $\mathrm{pH}$ sensitive copolymers for biofilm targeting.

\section{Materials and methods}

\section{Materials}

Reagents

The copolymers of $\mathrm{PLA}_{5 \mathrm{~K}}-\mathrm{PAE}_{5 \mathrm{~K}}-\mathrm{mPEG}_{5 \mathrm{~K}}$, $\mathrm{PAE}_{5 \mathrm{~K}}-\mathrm{PLA}_{5 \mathrm{~K}}-\mathrm{mPEG}_{5 \mathrm{~K}}$ and $\mathrm{PLA}_{5 \mathrm{~K}}-\mathrm{PEG}_{5 \mathrm{~K}}-\mathrm{PAE}_{5 \mathrm{~K}}$ were purchased from Ruixi Biological Technology Co., Ltd (Xi'an, Shanxi, China). The details of synthesis and characterization of the copolymers were shown in the Additional file 1. Biotin LPS and A LIVE/DEAD ${ }^{\circledR}$ BacLight $^{\text {TM }}$
Bacterial Viability Kit were obtained from Nanocs, Inc. (New York, USA) and Thermo Fisher Scientific Inc. (Shanghai, China), respectively. Nile red and Triclosan (TCS) were obtained from Macklin Biochemical Co., Ltd (Shanghai, China).

\section{Bacteria}

Two bacteria strains, Staphylococcus aureus ATCC 29213 and Escherichia coli ATCC 25922, were obtained from American Type Culture Collection (VA, USA), which were maintained in $30 \%$ glycerol at $-80^{\circ} \mathrm{C}$ until use.

\section{Animals}

Male Sprague-Dawley rats (220-250 g) were subject to the in vivo treatment of implant-related biofilm infection. The SD rats were obtained from Pengyue Laboratory 
Animal Breeding Co., Ltd (Jinan, Shandong, China) and the animal studies were conducted according to the experimental protocols by Institutional Animal Care and Use Committee of Binzhou Medical University.

\section{Micellar formulations}

$\mathrm{M}_{\mathrm{L}-\mathrm{E}-\mathrm{A}}$ : blank $\mathrm{pH}$-sensitive surface charge-adaptive micelles composed of PLA-PEG-PAE;

$\mathrm{M}_{\mathrm{L}-\mathrm{A}-\mathrm{E}}$ : blank $\mathrm{pH}$-sensitive surface charge-adaptive micelles composed of PLA-PAE-mPEG;

$\mathrm{M}_{\mathrm{A}-\mathrm{L}-\mathrm{E}}$ : blank $\mathrm{pH}$-sensitive surface charge-adaptive micelles composed of PAE-PLA-mPEG;

$\mathrm{M}_{\mathrm{L}-\mathrm{E}-\mathrm{A}} / \mathrm{TCS}: \mathrm{M}_{\mathrm{L}-\mathrm{E}-\mathrm{A}}$ loaded with TCS;

$\mathrm{M}_{\mathrm{L}-\mathrm{A}-\mathrm{E}} / \mathrm{TCS}: \mathrm{M}_{\mathrm{L}-\mathrm{A}-\mathrm{E}}$ loaded with TCS;

$\mathrm{M}_{\mathrm{L}-\mathrm{E}-\mathrm{A}} / \mathrm{Nile}$ Red: $\mathrm{M}_{\mathrm{L}-\mathrm{E}-\mathrm{A}}$ loaded with Nile Red;

$\mathrm{M}_{\mathrm{L}-\mathrm{A}-\mathrm{E}} / \mathrm{Nile}$ Red: $\mathrm{M}_{\mathrm{L}-\mathrm{A}-\mathrm{E}}$ loaded with Nile Red.

\section{Methods}

\section{Triggering $\mathrm{pH}\left(\mathrm{pH}_{\mathrm{t}}\right)$ analysis}

$\mathrm{M}_{\mathrm{L}-\mathrm{A}-\mathrm{E}}, \mathrm{M}_{\mathrm{L}-\mathrm{E}-\mathrm{A}}$ and $\mathrm{M}_{\mathrm{A}-\mathrm{L}-\mathrm{E}}$ were fabricated by the thinfilm hydration method [26]. Briefly, $50 \mathrm{mg}$ of PLAPAE-mPEG, PLA-PEG-PAE and PAE-PLA-mPEG were dissolved in $20 \mathrm{ml}$ of dichloromethane, respectively. Then, the solvent was removed by rotary evaporation to allow the film forming. After that, the film was hydrated with $20 \mathrm{~mL}$ of PBS (pH 7.4), and filtrated through a $0.22 \mu \mathrm{m}$ film to obtain micellar solution. Finally, the $\mathrm{pH}$ of $\mathrm{M}_{\mathrm{L}-\mathrm{E}-\mathrm{A}}, \mathrm{M}_{\mathrm{L}-\mathrm{A}-\mathrm{E}}$ and $\mathrm{M}_{\mathrm{A}-\mathrm{L}-\mathrm{E}}$ was adjusted to 3.0, 4.0, 4.5, 5.0. 5.5 and 6.0, respectively. The zeta potential of each micellar preparation was measured on a Zetasizer Nano ZS analyzer (DLS, Malvern, UK).

\section{pH-dependent physicochemical properties}

The changes of morphology, particle size and zeta potential of $\mathrm{M}_{\mathrm{L}-\mathrm{E}-\mathrm{A}}$ and $\mathrm{M}_{\mathrm{L}-\mathrm{A}-\mathrm{E}}$ under $\mathrm{pH} 7.4$ and 5.5 over time were investigated on a JEM1400 transmission electron microscopy (TEM, JEOL, Japan) and a Zetasizer Nano ZS analyzer (DLS, Malvern, UK), respectively.

\section{Micelles-bacterium binding studies}

Zeta potential analysis The planktonic bacteria-micelle binding study was initialized by adding $10 \mathrm{~mL}$ of the tested blank micelles $\left(\mathrm{M}_{\mathrm{L}-\mathrm{E}-\mathrm{A}}\right.$ and $\left.\mathrm{M}_{\mathrm{L}-\mathrm{A}-\mathrm{E}}\right)$ to $10 \mathrm{~mL}$ of bacterial suspensions $\left(10^{8} \mathrm{CFU}\right)$ with $\mathrm{pH}$ values adjusted to 5.5 and 7.4, respectively. The zeta potential of the micelles/ bacteria mixture was measured on a Zetasizer Nano ZS analyzer (Malvern, UK) for each solution with time points ranging from 0 to $24 \mathrm{~h}$.

Confocal laser scanning microscope (CLSM) The bacteria were suspended in $\mathrm{PBS}$ at $\mathrm{pH}$ of 5.5 or 7.4, and incubated with $\mathrm{M}_{\mathrm{L}-\mathrm{E}-\mathrm{A}} / \mathrm{Nile}$ Red or $\mathrm{M}_{\mathrm{L}-\mathrm{A}-\mathrm{E}} / \mathrm{Nile}$ Red solutions, respectively. As scheduled time points $(1,2,4$ and $8 \mathrm{~h})$, the unbound micelles were removed by rinsing the bacteria solution twice with saline, and the bacteria were resuspended in $100 \mu \mathrm{L}$ PBS at $\mathrm{pH}$ 7.4. The red fluorescence was measured at $\lambda$ ex $(583 \mathrm{~nm}) / \lambda \mathrm{em}(688 \mathrm{~nm})$ to obtain the microscope images by a Leica TCS SPE Microsystems (Wetzlar, Germany). Fiji Image J software was used to measure the relative red fluorescence intensity.

Flow cytometry assays The red fluorescence data of the bacterial suspensions prepared in the CLSM section was also acquired by BD FACSCanto II flow cytometry (USA). The fluorescence intensity of the cells was calculated by means of the histogram plot with the untreated negative sample as control.

Bio-layer interferometry (BLI) The BLI study was performed on Octet RED 96e (ForteBio, USA). The $\mathrm{pH}$ of $\mathrm{M}_{\mathrm{L}-\mathrm{E}-\mathrm{A}}$ and $\mathrm{M}_{\mathrm{L}-\mathrm{A}-\mathrm{E}}$ was firstly adjusted to 7.4 and 5.5 , respectively. The biotin-linked lipopolysaccharide (b-LPS) was loaded on streptavidin (SA) biosensor. Association and dissociation experiments were conducted for 90 and 120 s, respectively.

\section{pH-dependent biofilm penetration}

$2 \mathrm{~mL}$ of bacteria was added into petri dishes and cultured for $4 \mathrm{~d}$ to establish mature biofilms. Then, the petri dishes with mature biofilms attached were incubated with $\mathrm{M}_{\mathrm{L}-\mathrm{E}-\mathrm{A}} / \mathrm{Nile}$ Red and $\mathrm{M}_{\mathrm{L}-\mathrm{A}-\mathrm{E}} /$ Nile Red for $1 \mathrm{~h}$, $2 \mathrm{~h}$ and $4 \mathrm{~h}$ under $\mathrm{pH} 7.4$ and 5.5, respectively. The biofilm images were obtained on a Zeiss LSM 880 (Zeiss, Germany) after stained with SYTO 9 for $30 \mathrm{~min}$. The Z-stack imaging was carried out using the areas near the center of the dishes at a $1-\mu \mathrm{m}$ interval.

\section{Preparation and characterization of TCS-loaded micelles}

The $\mathrm{M}_{\mathrm{L}-\mathrm{E}-\mathrm{A}} / \mathrm{TCS}$ and $\mathrm{M}_{\mathrm{L}-\mathrm{A}-\mathrm{E}} / \mathrm{TCS}$ were also prepared by thin-film hydration method with $10 \mathrm{mg}$ of TCS loaded. The morphology of the micelles was investigated on a JEM1400 TEM (JEOL, Japan), and the particle size and zeta potential were measured on a Zetasizer Nano ZS (Malvern, UK). Drug loading coefficient (DL\%) was calculated by Eq. (1):

$$
D L \%=\frac{\text { Weight of the drug in micelles }}{\text { Weight of the feeding copolymer and drug }} \times 100 \%,
$$

The entrapment efficiency (EE\%) was calculated by Eq. (2):

$$
E E \%=\frac{\text { Weight of the drug in micelles }}{\text { Weight of the feeding drug }} \times 100 \% .
$$


A dialysis bag (WM, 12-14 $\mathrm{kDa}$ ) containing $2 \mathrm{~mL}$ freshly prepared $\mathrm{M}_{\mathrm{L}-\mathrm{E}-\mathrm{A}} / \mathrm{TCS}$ and $\mathrm{M}_{\mathrm{L}-\mathrm{A}-\mathrm{E}} / \mathrm{TCS}$ was incubated in $20 \mathrm{~mL}$ PBS $(10 \mathrm{mM}, \mathrm{pH} 5.5$ or $\mathrm{pH} 7.4)$, and aliquots of the dialysis solution were collected at predetermined time intervals, which was subject to absorbance measurement at $281 \mathrm{~nm}$ on a Synergy H1 microplate reader (Biotek Instruments, Inc., USA). The cumulative drug release $v s$ time was plotted. The Lipase-triggered release behavior of TCS was studied after adding Lipase to PBS $(10 \mathrm{mM}, \mathrm{pH} 5.5$ or $\mathrm{pH} 7.4)$ with a final concentration of $0.5 \mathrm{mg} / \mathrm{mL}$ as described above.

\section{In vitro antibacterial activity against planktonic bacteria} Minimum inhibitory concentration The minimal inhibitory concentrations (MICs) of free TCS or TCS-loaded micelles $\left(\mathrm{M}_{\mathrm{L}-\mathrm{E}-\mathrm{A}} / \mathrm{TCS}\right.$ and $\left.\mathrm{M}_{\mathrm{L}-\mathrm{A}-\mathrm{E}} / \mathrm{TCS}\right)$ were determined against S. aureus ATCC 29213 and E. coli ATCC 25922 under $\mathrm{pH} 7.4$ or 5.5 by a micro-dilution method [27, 28]. The experiments were performed in six replicates with the bacteria suspensions as the negative control.

Live/dead assay The viability of the bacteria (ca. $10^{7} \mathrm{CFU} / \mathrm{mL}$ ) treated with free TCS or TCS-loaded micelles was evaluated for different periods of time $(1-12 \mathrm{~h})$ at pH 5.5 or 7.4 using a LIVE/DEAD BacLight Bacterial Viability Kit. After incubation, the bacteria were stained with a dye mixture of SYTO 9 dye and propidium iodide $(1: 1)$ at $25^{\circ} \mathrm{C}$ for $30 \mathrm{~min}$, and the fluorescent images were obtained using a Leica TCS SPE (Wetzlar, Germany).

\section{Biofilm susceptibility}

The effects of free TCS and TCS-loaded micelles on the mature biofilms of E. coli and S. aureus were discussed by CLSM. The biofilms were incubated with free TCS or TCS-loaded micelles $(4-64 \mu \mathrm{g} / \mathrm{mL}, \mathrm{pH} 7.4$ or 5.5$)$ for $24 \mathrm{~h}$, and then stained with a LIVE/DEAD BacLight Bacterial Viability Kit. The residual biofilm images were obtained through a Zeiss LSM 880 microscopy (Zeiss, Germany). The Z-stack imaging was conducted using the areas near the center of the dishes at a $1-\mu \mathrm{m}$ interval.

\section{In vivo treatment of biofilms on catheters}

The in vivo anti-biofilm efficiency of $\mathrm{M}_{\mathrm{L}-\mathrm{E}-\mathrm{A}} / \mathrm{TCS}$ and $\mathrm{M}_{\mathrm{L}-\mathrm{A}-\mathrm{E}} / \mathrm{TCS}$ was investigated on implant-related biofilm infection. Ten-mm segments of commercial catheters were incubated in E. coli suspensions at $37{ }^{\circ} \mathrm{C}$ for $96 \mathrm{~h}$ to establish mature biofilms, then washed twice with saline and subcutaneously implanted in the inner thigh of Sprague-Dawley rats under sterile environment. The rats were intravenously treated with $500 \mu \mathrm{L} \mathrm{M}_{\mathrm{L}-\mathrm{E}-\mathrm{A}} / \mathrm{TCS}$ and $\mathrm{M}_{\mathrm{L}-\mathrm{A}-\mathrm{E}} / \mathrm{TCS}$ or free TCS at a dose of $2 \mathrm{mg} / \mathrm{kg}$ once daily for 7 days. The body weight of the rats was recorded daily from the first day to the end of the treatment.

At the end of the experiment, the implanted catheters and surrounding tissues were retrieved after the rats were euthanatized. The biofilm eradication was evaluated through SEM observation (Zeiss EVO LS15, Oberkochen, Germany). The bacteria growth rate was determined by calculating the colony-forming units (CFUs) after the bacteria were dispersed under low energy sonication for $45 \mathrm{~min}$ and incubated at $37^{\circ} \mathrm{C}$ for $12 \mathrm{~h}$. In addition, the retrieved tissue and major organs (heart, liver, spleen, lung and kidney) were observed under an optical microscope after stained with H\&E.

\section{Statistical analyses}

The data were presented as mean \pm standard deviation (S.D). Student's $t$-test was used to compare the difference between two groups. Statistical significance was defined as ${ }^{*} P<0.05,{ }^{* *} P<0.01,{ }^{* * * *} P<0.001$ and ${ }^{* * * *} P<0.0001$.

\section{Results and discussion}

\section{Incorporation of PAE in the triblock copolymers}

Due to the different $\mathrm{pH}$ between the vicinity of the biofilm $(\approx 5.5)$ and healthy tissues $(\approx 7.4)$, it is necessary for the $\mathrm{pH}$-sensitive copolymers to have an appropriate triggering $\mathrm{pH}\left(\mathrm{pH}_{\mathrm{t}}\right)$ around 5.5. The $\mathrm{pH}_{\mathrm{t}}$ of $\mathrm{M}_{\mathrm{A}-\mathrm{L}-\mathrm{E}}, \mathrm{M}_{\mathrm{L}-\mathrm{A}-\mathrm{E}}$ and $\mathrm{M}_{\mathrm{L}-\mathrm{E}-\mathrm{A}}$ was investigated by testing the $\mathrm{pH}$-dependent zeta potential. As shown in Fig. 2, the $\mathrm{pH}_{\mathrm{t}}$ of $\mathrm{M}_{\mathrm{A}-\mathrm{L}-\mathrm{E}}$, $\mathrm{M}_{\mathrm{L}-\mathrm{A}-\mathrm{E}}$ and $\mathrm{M}_{\mathrm{L}-\mathrm{E}-\mathrm{A}}$ was around 4.0, 5.5 and 6.0. Previous studies indicated that the $\mathrm{pK}_{\mathrm{b}}$ of PAE segments was around $6.5[29,30]$, which suggested that the distribution of PAE segments in the polymer chains would significantly affect its protonation capability. Among the tested copolymers, $\mathrm{M}_{\mathrm{A}-\mathrm{L}-\mathrm{E}}$ showed the lowest $\mathrm{pH}_{\mathrm{t}}$, which meant that $\mathrm{M}_{\mathrm{A}-\mathrm{L}-\mathrm{E}}$ demanded more tertiary amine groups in the PAE segments protonated at much lower $\mathrm{pH}$ to switch

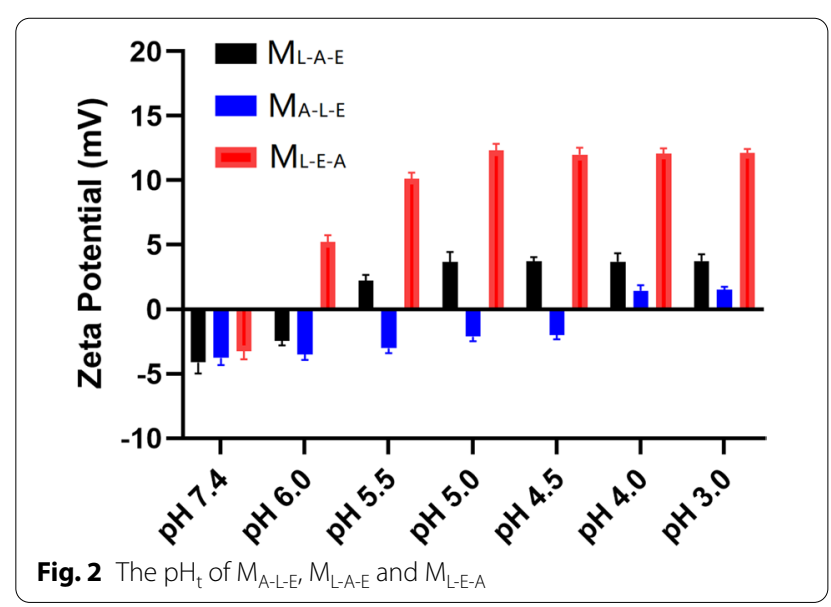


the surface charge. This might be due to that the PAE segments distantly located from the micellar surface and separated with the PEG segments. Thus, PAE segments would be preferentially placed near the micellar surface and associated with PEG segments. This was significantly in that it would facilitate the PAE segments rising to the surface due to the relatively hydrophilicity under acidic conditions and association with the PEG. Additionally, the $\mathrm{pH}_{\mathrm{t}}$ of $\mathrm{M}_{\mathrm{L}-\mathrm{A}-\mathrm{E}}$ was a little lower than that of $\mathrm{M}_{\mathrm{L}-\mathrm{E}-\mathrm{A}}$, which might be attributed to the additional hydrophobic force arising from the linkage with PLA segments. Due to the very acidic $\mathrm{pH}_{\mathrm{t}}$ of $\mathrm{M}_{\mathrm{A}-\mathrm{L}-\mathrm{E}}$, it is not suitable for targeting biofilms. Both $\mathrm{M}_{\mathrm{L}-\mathrm{A}-\mathrm{E}}$ and $\mathrm{M}_{\mathrm{L}-\mathrm{E}-\mathrm{A}}$ were found to display a desirable $\mathrm{pH}_{\mathrm{t}}(\sim 5.5)$, which could specifically respond to the biofilm environment $\mathrm{pH}$, and selected for the next study.

\section{$\mathrm{pH}$-dependent physicochemical properties of micelles}

The particle size and zeta potential of $\mathrm{M}_{\mathrm{L}-\mathrm{A}-\mathrm{E}}$ and $\mathrm{M}_{\mathrm{L}-\mathrm{E}-\mathrm{A}}$ was measured at different $\mathrm{pH}$ conditions to investigate the $\mathrm{pH}$-dependent physicochemical properties. As shown in Fig. 3A, both $\mathrm{M}_{\mathrm{L}-\mathrm{A}-\mathrm{E}}$ and $\mathrm{M}_{\mathrm{L}-\mathrm{E}-\mathrm{A}}$ could keep negatively charged with minor changes at $\mathrm{pH}$ 7.4. The surface charge of $\mathrm{M}_{\mathrm{L}-\mathrm{E}-\mathrm{A}}$ could quickly switch to a positive one $(\approx+16$ $\mathrm{mv}$ ) within $2 \mathrm{~h}$ at $\mathrm{pH}$ 5.5. In contrast, the zeta potential of $\mathrm{M}_{\mathrm{L}-\mathrm{A}-\mathrm{E}}$ only switched from $-4.11 \mathrm{mV}$ to $+4.74 \mathrm{mV}$ at $\mathrm{pH}$ 5.5, and the transition took more than $4 \mathrm{~h}$. We reasoned that the longer transform time and lower zeta potential transition of $\mathrm{M}_{\mathrm{L}-\mathrm{A}-\mathrm{E}}$ was attributed to (1) compared with $\mathrm{M}_{\mathrm{L}-\mathrm{E}-\mathrm{A}}$, the PAE segments in $\mathrm{M}_{\mathrm{L}-\mathrm{A}-\mathrm{E}}$ needed to be more ionized in order to break the additional hydrophobic force arising from the close association with PLA segments, which needed more time. (2) After ionized fully, the outmost PEG shell would still cover the positive charged $\mathrm{PAE}^{+}$.

The size variation of $\mathrm{M}_{\mathrm{L}-\mathrm{A}-\mathrm{E}}$ and $\mathrm{M}_{\mathrm{L}-\mathrm{E}-\mathrm{A}}$ under different $\mathrm{pH}$ conditions was also measured with the incubation time extending (Fig. 3B). The particle size of both $\mathrm{M}_{\mathrm{L}-\mathrm{A}-\mathrm{E}}$ and $\mathrm{M}_{\mathrm{L}-\mathrm{E}-\mathrm{A}}$ showed no obvious change after incubation at $\mathrm{pH} 7.4$ for $24 \mathrm{~h}$, indicating the good stability at the physiological condition. Under $\mathrm{pH} 5.5$, the particle size of $\mathrm{M}_{\mathrm{L}-\mathrm{E}-\mathrm{A}}$ firstly increased within $1 \mathrm{~h}$ of incubation. The reason may be that PAE protonated and began to disassociate from the hydrophobic core. The micelles transformed from dense to loosen structure, which led to an increase of the particle size around $20 \mathrm{~nm}$ [31] Further extending the incubation time, the particle size started to decrease until $2 \mathrm{~h}$, and then leveled off. This was probably because that the tertiary diamine moieties of PAE were fully ionized after $2 \mathrm{~h}$ of incubation, and the new cationic micelles $\left(\mathrm{M}_{\mathrm{L}-\mathrm{E}-\mathrm{A}}{ }^{+}\right)$with PLA as the inner core and PEG/ $\mathrm{PAE}^{+}$as the mixed shell formed, and the corresponding size was around $120 \mathrm{~nm}$. Obviously, the micelle size of $\mathrm{M}_{\mathrm{L}-\mathrm{E}-\mathrm{A}}$ was a little bigger than that of $\mathrm{M}_{\mathrm{L}-\mathrm{E}-\mathrm{A}}{ }^{+}$. This might be attributed to the more hydrophobic core content, the bigger particle size. In contrast, the particle size of $M_{L-A-E}$ kept increasing with the incubation time extending to $4 \mathrm{~h}$, which was also attributed to the protonation of PAE segments, leading to a loosen structure. Different from $\mathrm{M}_{\mathrm{L}-\mathrm{E}-\mathrm{A}}$, further extending the incubation time, the particle size just stopped increasing without shrinking, and reached a plateau. This was probably because the electrostatic repulsion between the $\mathrm{PAE}^{+}$segments induced the swelling of PAE residues. The closely associated PLA segments could not form tight inner core under this condition. TEM images demonstrated that $\mathrm{M}_{\mathrm{L}-\mathrm{A}-\mathrm{E}}$ and $\mathrm{M}_{\mathrm{L}-\mathrm{E}-\mathrm{A}}$ appeared round and smooth under both $\mathrm{pH}$ 7.4 and 5.5 (Fig. 3C). Further prolonging the incubation time, both $\mathrm{M}_{\mathrm{L}-\mathrm{A}-\mathrm{E}}$ and $\mathrm{M}_{\mathrm{L}-\mathrm{E}-\mathrm{A}}$ could retain the micellar integrity under acidic (Fig. 3D), which could enable the slow releasing behavior of the loaded drugs and tailor micelles-bacterium interactions.

\section{pH-dependent micelles-bacteria binding and penetration into biofilms}

We wondered whether the different $\mathrm{pH}$-dependent physicochemical properties of $\mathrm{M}_{\mathrm{L}-\mathrm{E}-\mathrm{A}}$ and $\mathrm{M}_{\mathrm{L}-\mathrm{A}-\mathrm{E}}$ could affect the binding affinity with bacteria, and then evaluated the micelles-bacterium interactions by a variety of experimental techniques. As shown in Fig. 4A, both $E$. coli and $S$. aureus remained $\mathrm{pH}$-insensitive and negatively charged with the zeta potential around - $11 \mathrm{mv}$ and $-12 \mathrm{mv}$, respectively. It could be observed that the binding affinity of $\mathrm{M}_{\mathrm{L}-\mathrm{E}-\mathrm{A}}$ was markedly influenced by $\mathrm{pH}$ values. At $\mathrm{pH} 7.4$, only a subtle increase of zeta potential was observed after incubation with $\mathrm{M}_{\mathrm{L}-\mathrm{E}-\mathrm{A}}$ in the case of both bacteria, indicating the limited binding affinity. However, the zeta potential of the bacteria increased rapidly and even reversed to a positive one when the $\mathrm{pH}$ dropped to 5.5, suggesting a large and increase in binding. Oppositely, although $\mathrm{M}_{\mathrm{L}-\mathrm{A}-\mathrm{E}}$ showed $\mathrm{pH}$-dependent targeting towards bacteria, the interactions between them remained low at $\mathrm{pH}$ 5.5. This demonstrated that the $\mathrm{pH}$-stimulated change in zeta potential and structure transition of micelles significantly affected the targeting ability to bacteria. For $\mathrm{M}_{\mathrm{L}-\mathrm{E}-\mathrm{A}}$, the PAE moieties could be ionized and rise to the surface as the outermost layer at acidic condition, resulted in the positive charge density of the micelles surface dramatically increasing. The increased positive surface charge could facilitate $\mathrm{M}_{\mathrm{L}-\mathrm{E}-\mathrm{A}}{ }^{+}$ targeting toward the negatively charged bacterial cell membrane. Although, the PAE segments in $\mathrm{M}_{\mathrm{L}-\mathrm{A}-\mathrm{E}}$ could also protonated at $\mathrm{pH} 5.5$, the weak positively charged surface and PEG shell would hamper the electrostatic interaction between cationic micelles and bacteria. 

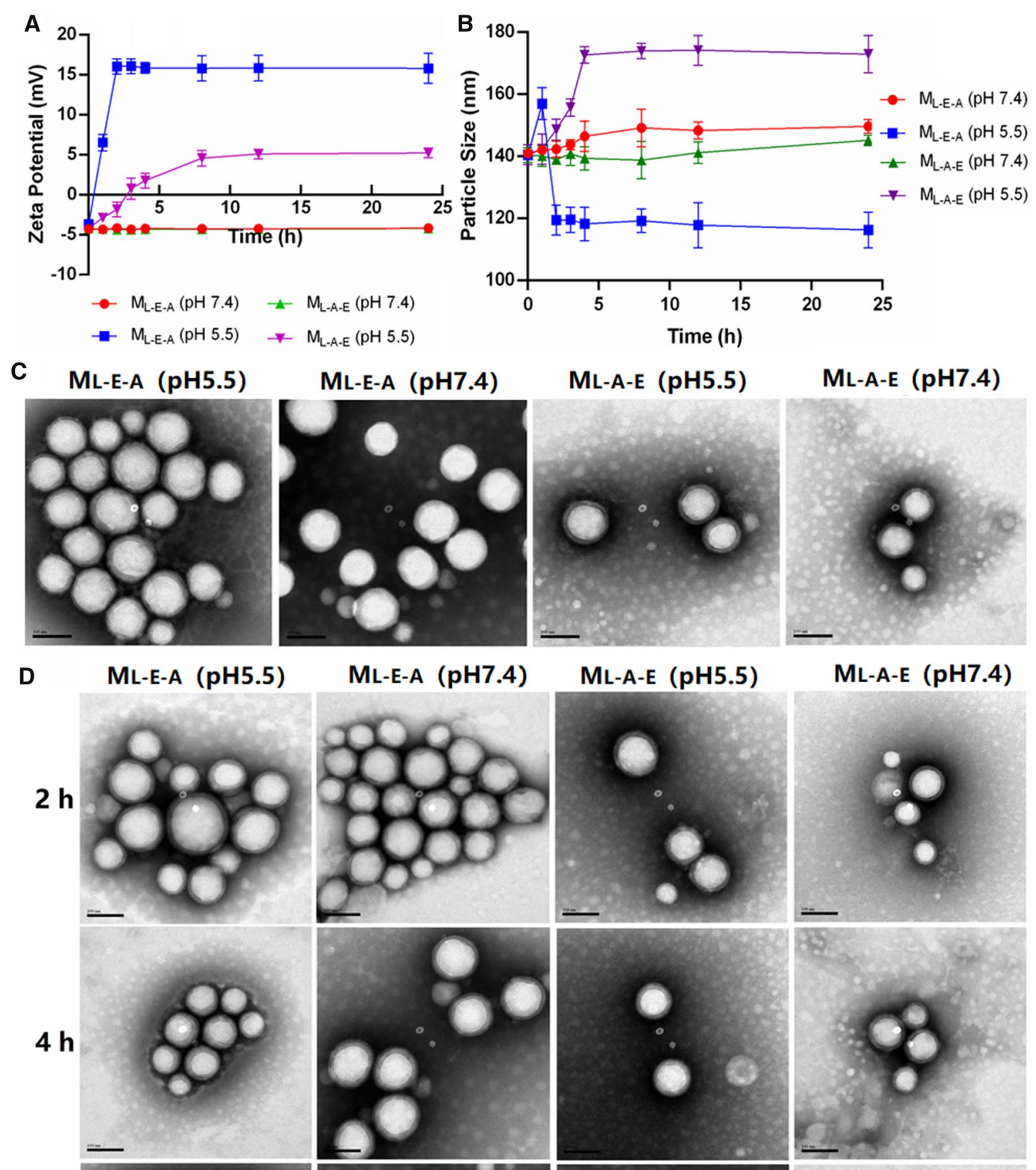

ML-A-E (pH7.4)
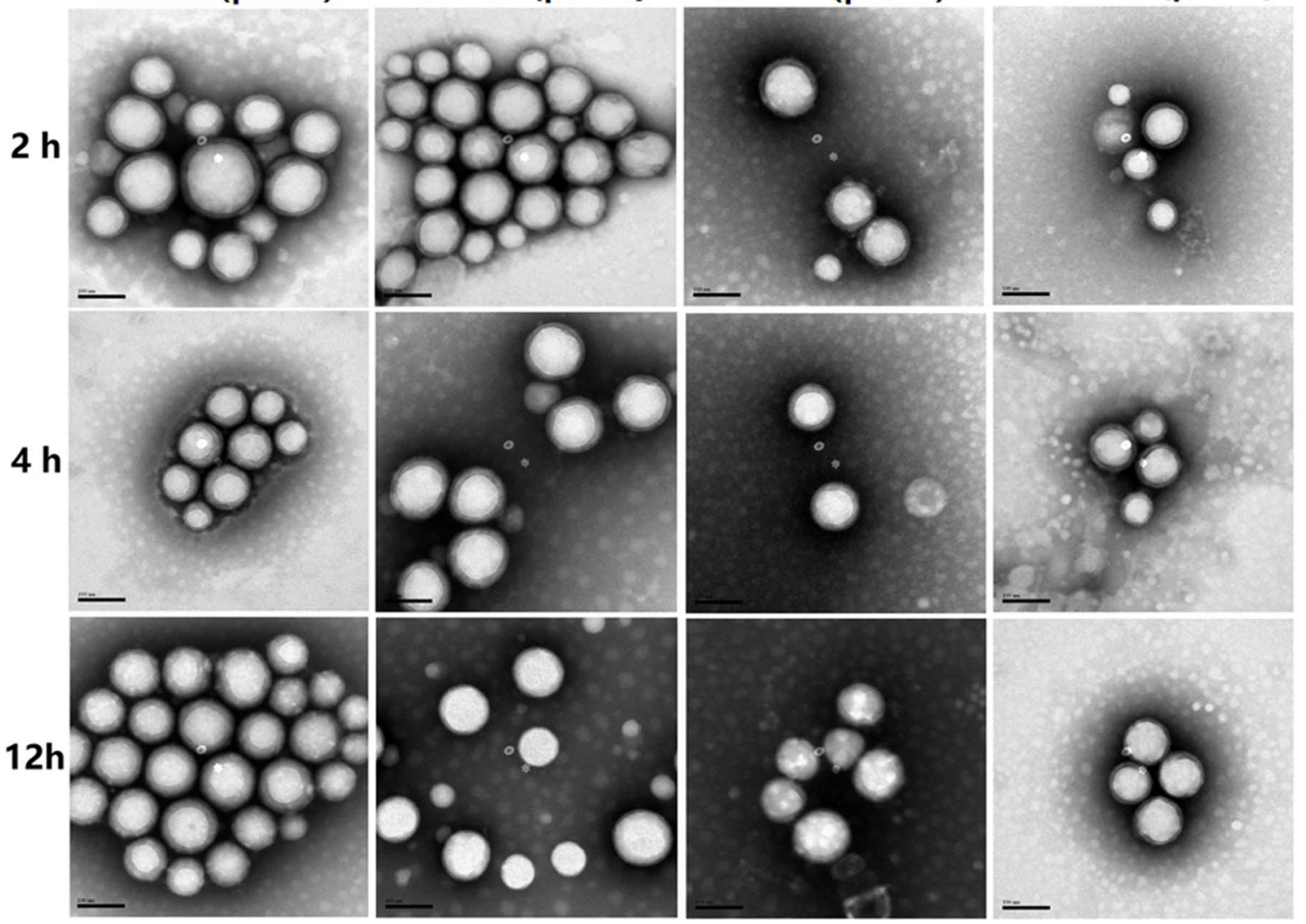

Fig. 3 The variations in Zeta potentials (A) and particle sizes (B) of $\mathrm{M}_{\mathrm{LE-EA}}$ and $\mathrm{M}_{\mathrm{LA-E}}$ Vs time under $\mathrm{pH}$ 7.4 and 5.5, respectively. Error bars denote the standard deviations. TEM images of $\mathrm{M}_{\mathrm{LEE}-\mathrm{A}}$ and $\mathrm{M}_{\mathrm{L}-\mathrm{A}-\mathrm{E}}$ obtained under $\mathrm{pH} 7.4$ and 5.5 (C). The morphology changes of $\mathrm{M}_{\mathrm{LEE}-\mathrm{A}}$ and $\mathrm{M}_{\mathrm{L}-\mathrm{A}-\mathrm{E}} \mathrm{Under} \mathrm{pH} 7.4$ and 5.5 with the time (D). Scale bars $=100 \mathrm{~nm}$. N=3 for all observations 
The $\mathrm{pH}$-dependent binding behavior of $\mathrm{M}_{\mathrm{L}-\mathrm{A}-\mathrm{E}}$ and $\mathrm{M}_{\mathrm{L}-\mathrm{E}-\mathrm{A}}$ to bacteria was further evaluated by CLSM. CLSM visually confirmed the $\mathrm{pH}$-sensitive nature of $\mathrm{M}_{\mathrm{L}-\mathrm{A}-\mathrm{E}}$ and $\mathrm{M}_{\mathrm{L}-\mathrm{E}-\mathrm{A}}$ binding to bacteria (Fig. 4B). It could be seen that the red fluorescence of both micelles concurrently increased with the decrease of $\mathrm{pH}$. Strong fluorescence could be seen at the $\mathrm{pH} 5.5$ groups but not $\mathrm{pH} 7.4$ groups. Moreover, the $\mathrm{pH}$-dependent increase in binding affinity of $\mathrm{M}_{\mathrm{L}-\mathrm{E}-\mathrm{A}}$ was more pronounced as compared to that of $\mathrm{M}_{\mathrm{L}-\mathrm{A}-\mathrm{E}}$. After $2 \mathrm{~h}$ of incubation at $\mathrm{pH}$ 5.5, the $\mathrm{M}_{\mathrm{L}-\mathrm{E}-\mathrm{A}} / \mathrm{Nile}$ red showed the strongest red fluorescence with the mean gray value around $65 \mathrm{AU}$, and the red fluorescence could last more than $8 \mathrm{~h}$ (Fig. 4C). Additionally, at the acidic condition, large aggregates of bacteria were observed after treated with $\mathrm{M}_{\mathrm{L}-\mathrm{E}-\mathrm{A}}$. This might be attributed to the bridge effect of positively charged $\mathrm{M}_{\mathrm{L}-\mathrm{E}-\mathrm{A}}{ }^{+}$trigging the negatively charged bacteria agglutination. The influence of $\mathrm{pH}$ on the binding ability of micelles with bacteria was further quantitatively investigated by flow cytometry. As shown in Fig. 4D, in line with the CLSM observation, a large amount of $\mathrm{M}_{\mathrm{L}-\mathrm{E}-\mathrm{A}}$ could be taken up by $E$. coli and $S$. aureus at $\mathrm{pH} 5.5$, and peaked at $2 \mathrm{~h}$.

Based on these results, we believed that the protonated $\mathrm{PAE}^{+}$segments played a critical role in binding to bacteria by electrostatic interacting with the negatively charged component of bacteria, e.g. lipopolysaccharide (LPS) or peptidoglycan (PGN). The binding affinity of $\mathrm{M}_{\mathrm{L}-\mathrm{A}-\mathrm{E}}$ and $\mathrm{M}_{\mathrm{L}-\mathrm{E}-\mathrm{A}}$ with LPS, one of the main structural components of the Gram-negative bacteria, was monitored and quantified using BLI at pH 5.5 and 7.4, respectively. According to the observed kinetics (Fig. 4E), the interactions between $\mathrm{M}_{\mathrm{L}-\mathrm{E}-\mathrm{A}}$ and LPS was significantly affected by the environment $\mathrm{pH}$. Under physiological $\mathrm{pH}$, the $\mathrm{M}_{\mathrm{L}-\mathrm{E}-\mathrm{A}}$ showed less affinity to LPS with an affinity constant $\left(\mathrm{K}_{\mathrm{D}}\right)$ of $1.57 \times 10^{-5} \mathrm{M}$, which was similar as that of $\mathrm{M}_{\mathrm{L}-\mathrm{A}-\mathrm{E}}\left(\mathrm{K}_{\mathrm{D}}, 4.82 \times 10^{-5}\right)$ (Table 1$)$. This stated that the negatively charged surface and PEG-shell would impede the micelles-LPS interactions due to the electrostatic repulsion and steric hindrance. When the $\mathrm{pH}$ lowered to 5.5, the interactions between $\mathrm{M}_{\mathrm{L}-\mathrm{E}-\mathrm{A}}$ and LPS significantly increased, and the $\mathrm{K}_{\mathrm{D}}$ decreased to $6.03 \times 10^{-7} \mathrm{M}$. However, there was no significant difference in $\mathrm{M}_{\mathrm{L}-\mathrm{A}-\mathrm{E}}$ over the $\mathrm{pH}$ trajectory. Thus, the enhanced binding affinity of $\mathrm{M}_{\mathrm{L}-\mathrm{E}-\mathrm{A}}$ under acidic condition could be due to the increased interactions with LPS. It was possible that $\mathrm{M}_{\mathrm{L}-\mathrm{E}-\mathrm{A}}$ may act in a similar way to $S$. aureus by interacting with the negatively-charged component of cell wall (e.g. peptidoglycan).

The stealth penetration and accumulation capability of $\mathrm{M}_{\mathrm{L}-\mathrm{A}-\mathrm{E}}$ and $\mathrm{M}_{\mathrm{L}-\mathrm{E}-\mathrm{A}}$ in biofilms were further evaluated using $S$. aureus and $E$. coli as the model organisms. The biofilms were incubated with the Nile red loaded micelles for $1 \mathrm{~h}, 2 \mathrm{~h}$ and $4 \mathrm{~h}$, and then stained by STYO 9. As depicted in Fig. 4F, demonstrable penetration and accumulation of red-fluorescent $\mathrm{M}_{\mathrm{L}-\mathrm{E}-\mathrm{A}}$ and $\mathrm{M}_{\mathrm{L}-\mathrm{A}-\mathrm{E}}$ at $\mathrm{pH}$ 7.4 was completely absent. At pH 5.5, $\mathrm{M}_{\mathrm{L}-\mathrm{E}-\mathrm{A}}$ and $\mathrm{M}_{\mathrm{L}-\mathrm{A}-\mathrm{E}}$ showed a completely different pattern of penetration of accumulation in biofilms. $\mathrm{M}_{\mathrm{L}-\mathrm{E}-\mathrm{A}} / \mathrm{Nile}$ red penetrated well into the biofilms, while rapid saturation of fluorescence and deep accumulation even to the biofilm bottom occurred within $1 \mathrm{~h}$ for both bacterial biofilms. Whereas $\mathrm{M}_{\mathrm{L}-\mathrm{A}-\mathrm{E}}$ did not show obvious sign of increased penetration and accumulation in biofilms at $\mathrm{pH}$ 5.5. Evidently, the targeted interaction of $\mathrm{M}_{\mathrm{L}-\mathrm{E}-\mathrm{A}}$ with bacteria allowed the penetration and accumulation into biofilms at a low $\mathrm{pH}$ condition by avoiding from being washed out.

\section{Characterization of TCS-loaded micelles}

A spherical and homogeneous morphology of both $\mathrm{M}_{\mathrm{L}-\mathrm{E}-\mathrm{A}} / \mathrm{TCS}$ and $\mathrm{M}_{\mathrm{L}-\mathrm{A}-\mathrm{E}} / \mathrm{TCS}$ was observed by TEM (Fig. 5A, B), and the particle size was consistent with that obtained by DLS (Fig. 5C, D). Moreover, the characteristics of the TCS-loaded $\mathrm{M}_{\mathrm{L}-\mathrm{E}-\mathrm{A}}$ and $\mathrm{M}_{\mathrm{L}-\mathrm{A}-\mathrm{E}}$ at $\mathrm{pH} 7.4$ were summarized in Table 2. Blank $\mathrm{M}_{\mathrm{L}-\mathrm{A}-\mathrm{E}}$ and $\mathrm{M}_{\mathrm{L}-\mathrm{E}-\mathrm{A}}$ had a similar diameter of around $140 \mathrm{~nm}$ (Fig. 3C), while the diameters increased to $180 \mathrm{~nm}$ and $160 \mathrm{~nm}$ after TCS being loaded (Fig. 5E). Both $\mathrm{M}_{\mathrm{L}-\mathrm{E}-\mathrm{A}} / \mathrm{TCS}$ and $\mathrm{M}_{\mathrm{L}-\mathrm{A}-\mathrm{E}} / \mathrm{TCS}$ were slightly negatively charged at $\mathrm{pH}$ 7.4. The nearly net surface charge would enable the micelles escaping from the opsonin recognization, and passively targeting the infection sites [32].

The in vitro release performances of $\mathrm{M}_{\mathrm{L}-\mathrm{E}-\mathrm{A}} / \mathrm{TCS}$ and $\mathrm{M}_{\mathrm{L}-\mathrm{A}-\mathrm{E}} / \mathrm{TCS}$ were evaluated under different conditions. It could be observed that under physiological condition, both micelles exhibited a sustained release pattern, only $40 \%$ of TCS released after $48 \mathrm{~h}$. When the $\mathrm{pH}$ was lower,

(See figure on next page.)

Fig. 4 Zeta potential changes of S. aureus and E. coli after incubation with $\mathrm{M}_{\mathrm{LEE}-\mathrm{A}}$ and $\mathrm{M}_{\mathrm{L}-\mathrm{A}-\mathrm{E}}$ under $\mathrm{pH} 7.4$ or 5.5 for different periods of time, respectively (A). CLSM images of S. aureus and E. coli incubated with Nile Red loaded $M_{L-E-A}$ and $M_{L-A-E}$ for $1 \mathrm{~h}, 2 \mathrm{~h}, 4 \mathrm{~h}$ and $8 \mathrm{~h}$, respectively (B). The mean gray value of CLSM images measured by Fiji ImageJ (C). Quantitative cellular uptake of $\mathrm{M}_{\mathrm{L}-\mathrm{E}-\mathrm{A}} /$ Nile red and $\mathrm{M}_{\mathrm{L}-\mathrm{A}-\mathrm{E}} / \mathrm{Nile}$ red in $\mathrm{S}$. aureus and $E$. coli evaluated by flow cytometry at pH 7.4 and 5.5 for $1 \mathrm{~h}, 2 \mathrm{~h}, 4 \mathrm{~h}$ and $8 \mathrm{~h}$, respectively (D). BLI assay for the interaction between b-LPS and $\mathrm{M}_{\mathrm{LEE}-\mathrm{A}}$ $(\mathrm{pH} 7.4), \mathrm{M}_{\mathrm{L}-\mathrm{A}-\mathrm{E}}(\mathrm{pH} 7.4), \mathrm{M}_{\mathrm{LEE}-\mathrm{A}}\left(\mathrm{pH}\right.$ 5.5) and $\mathrm{M}_{\mathrm{L-A}-\mathrm{E}}\left(\mathrm{pH}\right.$ 5.5) (E). CLSM images of biofilms penetration of $\mathrm{M}_{\mathrm{LE}-\mathrm{A}} / \mathrm{Nile}$ red and $\mathrm{M}_{\mathrm{L}-\mathrm{A}-\mathrm{E}} / \mathrm{Nile}$ red at $\mathrm{pH} 5.5$ and 7.4 after $1 \mathrm{~h}, 2 \mathrm{~h}$ and $4 \mathrm{~h}$ of incubation, respectively. Scale bars $=100 \mu \mathrm{m}(\mathbf{F})$ 
Gro et al. J Nanobiotechnol

(2021) 19:232

Page 9 of 18

A
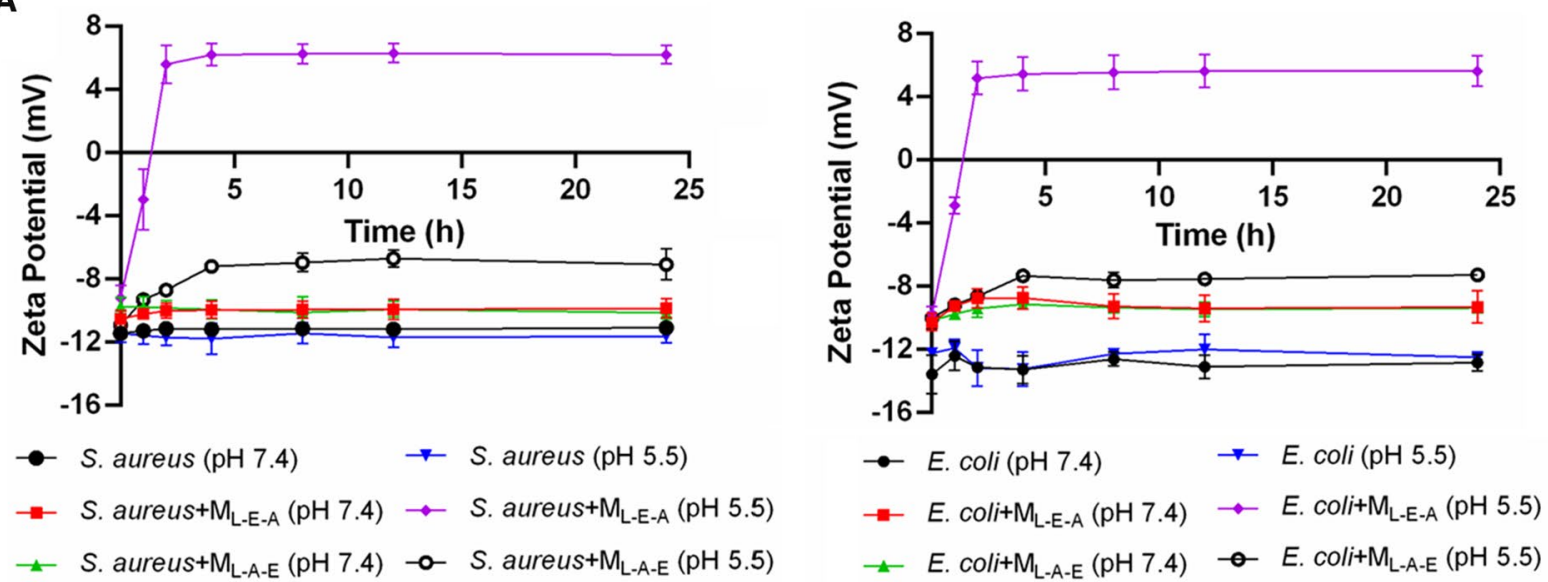

-- S. aureus (pH 7.4)

S. aureus ( $\mathrm{pH} 5.5)$

$\rightarrow$ S. aureus $+M_{\mathrm{L}-\mathrm{E}-\mathrm{A}}(\mathrm{pH} 7.4) \rightarrow S$. aureus $+\mathrm{M}_{\mathrm{L}-\mathrm{E}-\mathrm{A}}(\mathrm{pH} 5.5)$

$\rightarrow$ S. aureus $+\mathrm{M}_{\mathrm{L}-\mathrm{A}-\mathrm{E}}(\mathrm{pH} 7.4) \rightarrow \mathrm{S}$. aureus $+\mathrm{M}_{\mathrm{L}-\mathrm{A}-\mathrm{E}}(\mathrm{pH} 5.5)$

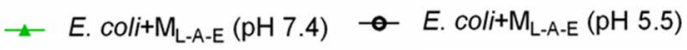

B

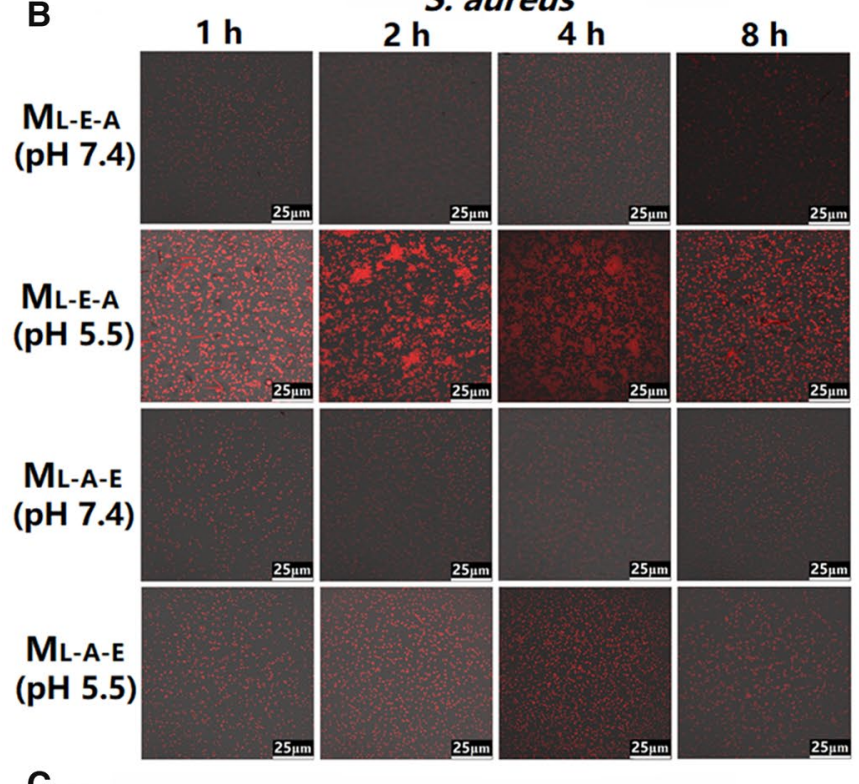

C

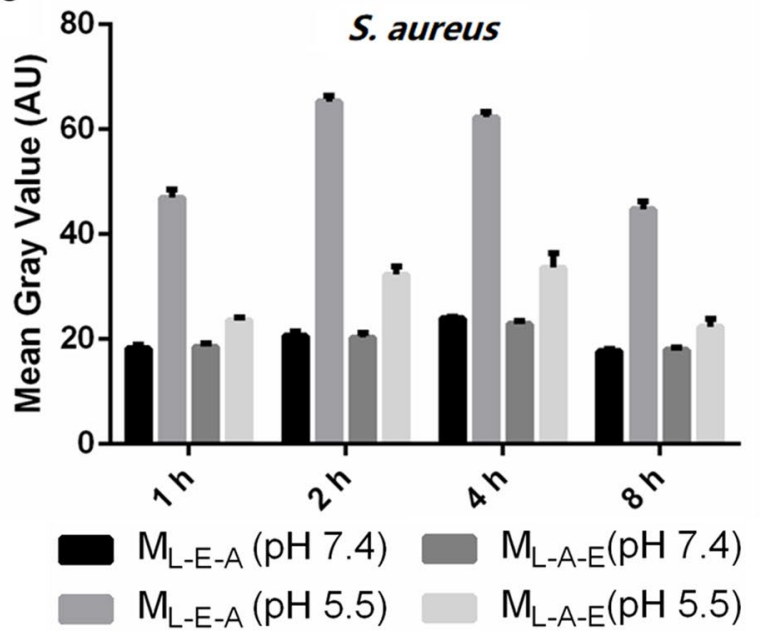

$1 \mathrm{~h}$
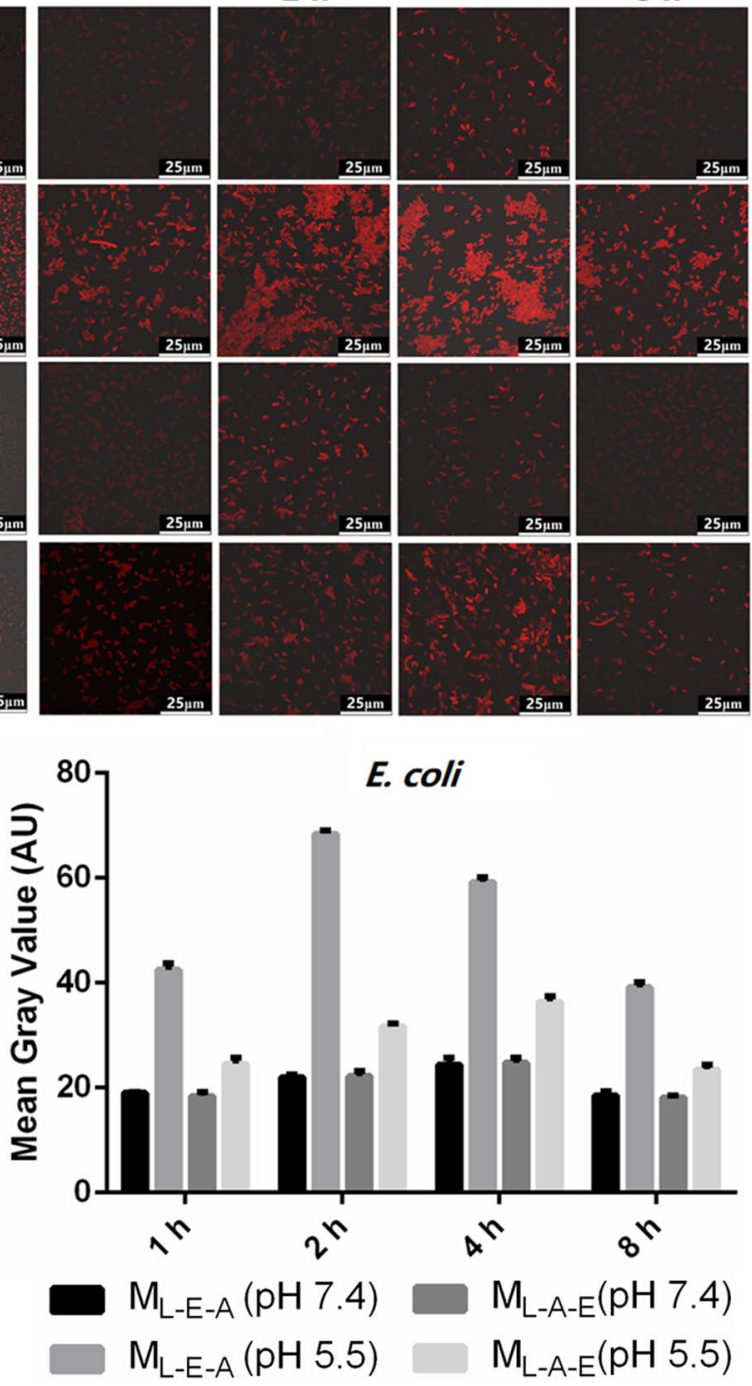

Fig. 4 See legend on previous page. 


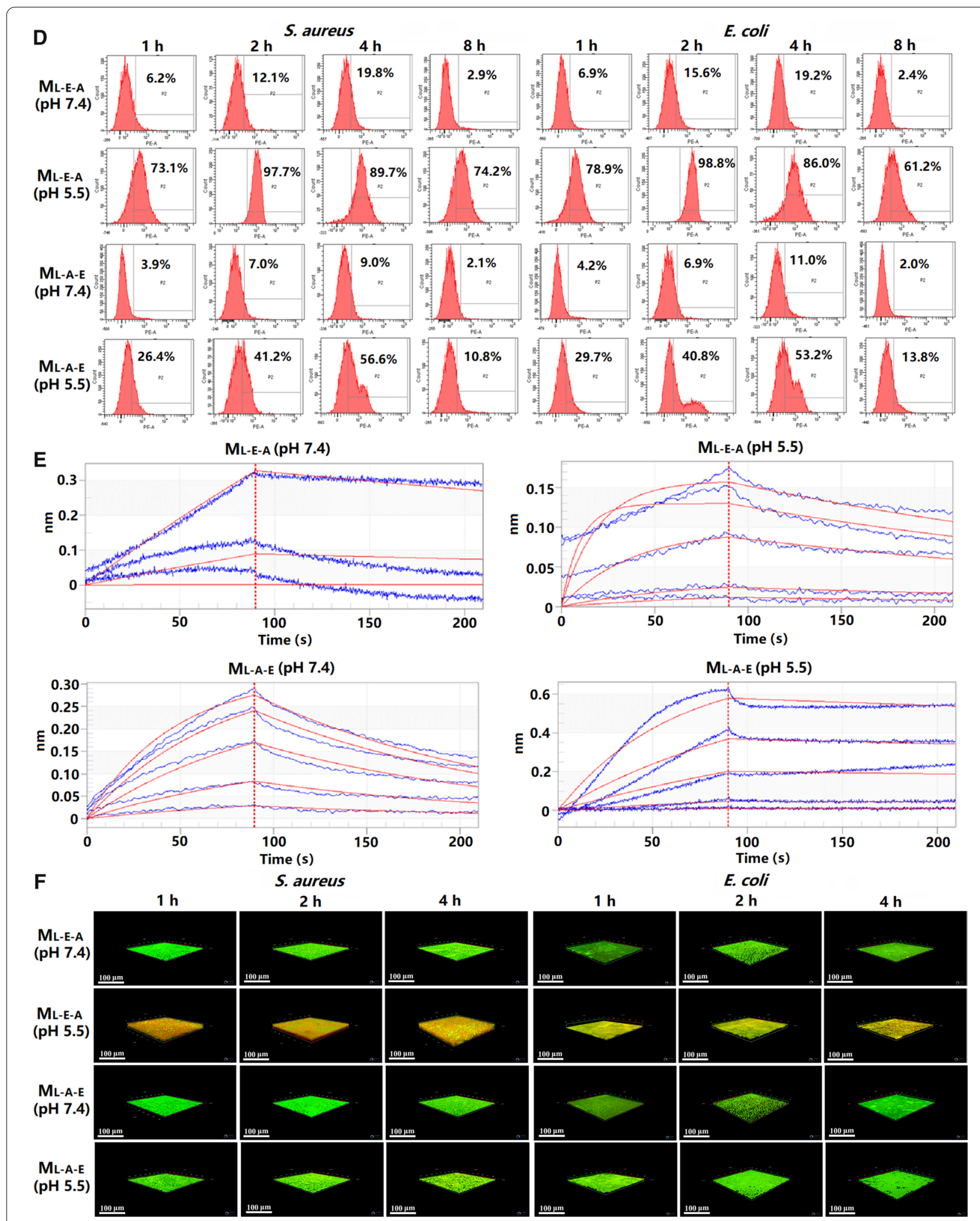

Fig. 4 continued 
Table 1 Binding parameters of $b-L P S$ with $M_{L-E-A}$ and $M_{L-A-E}$ under different $\mathrm{pHs}$ measured by BLI

\begin{tabular}{llll}
\hline Analyte & $\mathbf{k}_{\text {on }}(\mathbf{1} / \mathbf{M s})$ & $\mathbf{k}_{\text {dis }}(\mathbf{1} / \mathbf{s})$ & $\mathbf{K}_{\mathbf{D}}(\mathbf{M})$ \\
\hline $\mathrm{M}_{\mathrm{LEE-A}}(\mathrm{pH} \mathrm{7.4)}$ & $4.61 \mathrm{E}+02$ & $7.25 \mathrm{E}-03$ & $1.57 \mathrm{E}-05$ \\
$\mathrm{M}_{\mathrm{L-A}-\mathrm{E}}(\mathrm{pH} 7.4)$ & $3.35 \mathrm{E}+01$ & $1.61 \mathrm{E}-03$ & $4.82 \mathrm{E}-05$ \\
$\mathrm{M}_{\mathrm{L-E}-\mathrm{A}}(\mathrm{pH} 5.5)$ & $1.03 \mathrm{E}+03$ & $6.23 \mathrm{E}-04$ & $6.03 \mathrm{E}-07$ \\
$\mathrm{M}_{\mathrm{L-A}-\mathrm{E}}(\mathrm{pH} 5.5)$ & $3.07 \mathrm{E}+03$ & $3.21 \mathrm{E}-03$ & $1.05 \mathrm{E}-06$ \\
\hline
\end{tabular}

the drug release was accelerated, and the cumulative release was over $60 \%$ for both $\mathrm{M}_{\mathrm{L}-\mathrm{E}-\mathrm{A}} / \mathrm{TCS}$ and $\mathrm{M}_{\mathrm{L}-\mathrm{A}-\mathrm{E}} /$ TCS. This could be due to the protonation of amino groups in PAE moieties at lower $\mathrm{pH}$ conditions leading to the micelle structure loose. Bacterial enzymes such as lipase can promote the hydrolysis of the PLA core, which may accelerate the release of the loaded drugs. In the presence of lipase, the release of TCS from both $\mathrm{M}_{\mathrm{L}-\mathrm{E}-\mathrm{A}} /$ TCS and $\mathrm{M}_{\mathrm{L}-\mathrm{A}-\mathrm{E}} / \mathrm{TCS}$ increased, with an overall release rate around $70 \%$ after $48 \mathrm{~h}$. Our results indicated that the loosen hydrophobic core of micelles under $\mathrm{pH} 5.5$ was amenable to enzymatic degradation, leading to a higher drug release rate. Thus, the stronger lipase liability in the drug release might enhance the biofilm destruction of TCS-loaded micelles.

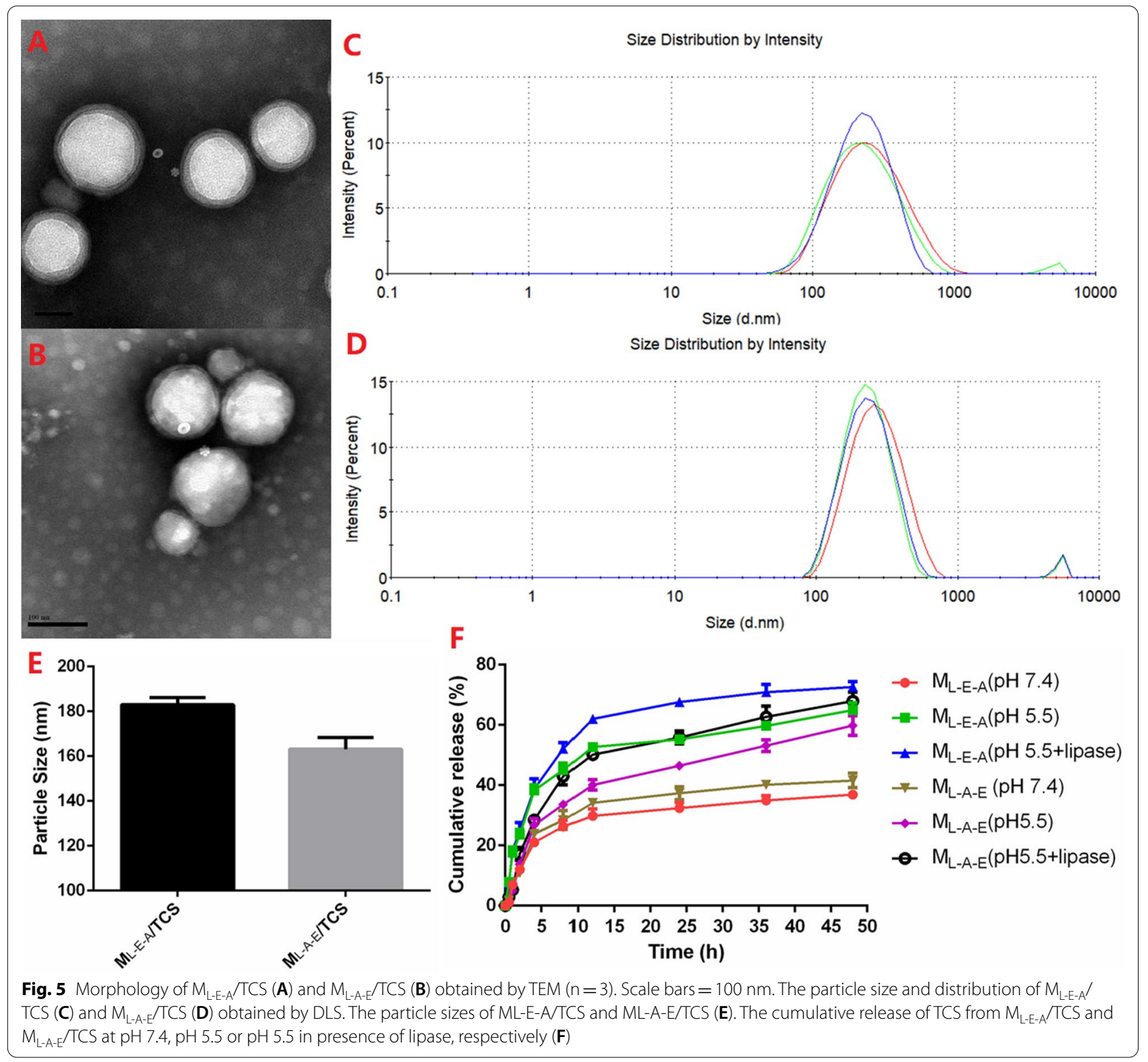


Table 2 The physicochemical characteristics of different micellar formulations $(n=3)$

\begin{tabular}{llllll}
\hline Formulations & Particle size $(\mathbf{n m})$ & Zeta potential $(\mathbf{m v})$ & PDI & DL\% & EE\% \\
\hline $\mathrm{M}_{\mathrm{L}-\mathrm{E}-\mathrm{A}} / \mathrm{TCS}$ & $182.97 \pm 3.12$ & $-1.95 \pm 0.398$ & $0.242 \pm 0.011$ & $7.92 \pm 0.21$ & $77.45 \pm 5.67$ \\
$\mathrm{M}_{\mathrm{L}-\mathrm{A}-\mathrm{E}} / \mathrm{TCS}$ & $163.13 \pm 5.23$ & $-2.64 \pm 0.149$ & $0.210 \pm 0.042$ & $8.05 \pm 0.24$ & $79.12 \pm 4.56$ \\
\hline
\end{tabular}

\section{Effect of TCS and TCS-loaded micelles on the growth of planktonic and biofilm bacteria}

We were also interested in whether the enhanced $\mathrm{pH}$ dependent binding affinity of $\mathrm{M}_{\mathrm{L-E}-\mathrm{A}}$ had an impact on its in vitro antibacterial efficacy and biofilm eradication and how this compared to $\mathrm{M}_{\mathrm{L}-\mathrm{A}-\mathrm{E}}$ and free TCS. The MICs of $\mathrm{M}_{\mathrm{L}-\mathrm{E}-\mathrm{A}} / \mathrm{TCS}, \mathrm{M}_{\mathrm{L}-\mathrm{A}-\mathrm{E}} / \mathrm{TCS}$ and free TCS for planktonic E. coli and S. aureus at $\mathrm{pH} 7.4$ and 5.5 were showed in Table 3. As expected, both bacteria appeared more susceptible to free TCS than to encapsulated TCS at pH 7.4, and free TCS was the most potent agent against plank-

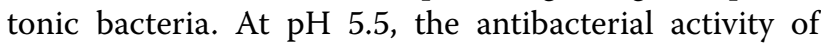
$\mathrm{M}_{\mathrm{L}-\mathrm{E}-\mathrm{A}} / \mathrm{TCS}$ was significantly improved, achieving a similar antibacterial effect compared with that of free TCS at the same concentration. Oppositely, the changing of $\mathrm{pH}$ did not influence the antibacterial activity of $\mathrm{M}_{\mathrm{L}-\mathrm{A}-\mathrm{E}} / \mathrm{TCS}$ dramatically. The difference between MIC ( $\mathrm{pH} \mathrm{5.5)} \mathrm{and}$ MIC ( $\mathrm{pH}$ 7.4) was very small and only involved one dilution steps.

The $\mathrm{pH}$-dependent bacterial viability after the treatment with free TCS, $\mathrm{M}_{\mathrm{L}-\mathrm{E}-\mathrm{A}} / \mathrm{TCS}$ and $\mathrm{M}_{\mathrm{L}-\mathrm{A}-\mathrm{E}} / \mathrm{TCS}$ was further measured using PI (red) and SYTO 9 (green). All the cells could be stained with green-fluorescent STYO 9. Only the dead ones with compromised membrane were stained red, and yielded yellow-fluorescent images. From the Fig. 6, most of the cells (both E. coli and S. aureus) treated with free TCS were fluorescing yellow at an exposure time of $1 \mathrm{~h}$, suggesting that most bacterial cells were dead within $1 \mathrm{~h}$. $\mathrm{M}_{\mathrm{L}-\mathrm{E}-\mathrm{A}} / \mathrm{TCS}$ showed comparable antibacterial effects after an exposure time of $2 \mathrm{~h}$ at $\mathrm{pH} 5.5$, but was ineffective at $\mathrm{pH}$ 7.4. This demonstrated that the surface charge changes of $\mathrm{M}_{\mathrm{L}-\mathrm{E}-\mathrm{A}}$ from negative to positive at the acidic environment could effectively enhance the bacterial capacity. Obviously, the bactericidal efficiency of $\mathrm{M}_{\mathrm{L}-\mathrm{E}-\mathrm{A}} / \mathrm{TCS}$ was time-needed compared with

Table 3 Antibacterial activities of the tested formulations

\begin{tabular}{|c|c|c|c|c|}
\hline \multirow[t]{3}{*}{ Formulations } & \multicolumn{4}{|c|}{ MIC $(\mu \mathrm{g} / \mathrm{mL})$} \\
\hline & \multicolumn{2}{|c|}{ S. aureus } & \multicolumn{2}{|l|}{ E. coli } \\
\hline & $\mathrm{pH} 7.4$ & pH 5.5 & $\mathrm{pH} 7.4$ & $\mathrm{pH} 5.5$ \\
\hline Triclosan & 1.0 & 2.0 & 4.0 & 4.0 \\
\hline$M_{\mathrm{L}-\mathrm{E}-\mathrm{A}} / \mathrm{TCS}$ & 8.0 & 1.0 & 32.0 & 4.0 \\
\hline$M_{\mathrm{L}-\mathrm{A}-\mathrm{E}} / \mathrm{TCS}$ & 8.0 & 4.0 & 32.0 & 16.0 \\
\hline
\end{tabular}

the effects of free TCS, since the protonation of PAE segments, enzymatic degradation of PLA core and releasing of TCS required time. Corresponding with MIC results, $\mathrm{pH}$ value did not play an important role in the antibacterial efficiency of $\mathrm{M}_{\mathrm{L}-\mathrm{A}-\mathrm{E}} / \mathrm{TCS}$.

Next, the killing efficacy of free TCS and TCS-loaded micelles was compared against bacteria in their biofilm mode of growth through CLSM observation, and the biofilm residues were also stained with live/dead staining. As illustrated in Fig. 7, free TCS showed limited effect against mature biofilms even at the highest concentration of $64 \mu \mathrm{g} / \mathrm{mL}$ at both pHs. Although the yellow-fluorescence was concentration-dependent, which indicated the decrease in the cell viability, the morphology of the biofilms had no change. Encapsulation TCS into micelles could promote its anti-biofilm activity, and a completely biofilm eradication could be observed at a concentration of $64 \mu \mathrm{g} / \mathrm{mL}$ for both $\mathrm{M}_{\mathrm{L}-\mathrm{A}-\mathrm{E}} / \mathrm{TCS}$ and $\mathrm{M}_{\mathrm{L}-\mathrm{A}-\mathrm{E}} / \mathrm{TCS}$ at $\mathrm{pH}$ 7.4. Under acidic condition, the biofilm eradication ability of both micelles was further improved, especially for the effects of $\mathrm{M}_{\mathrm{L}-\mathrm{E}-\mathrm{A}} / \mathrm{TCS}$. A dramatic decrease in biofilm thickness and bacterial viability was obtained at a lower concentration of $8 \mu \mathrm{g} / \mathrm{mL}$ against both $E$. coli and $S$. aureus. Infection control of bacteria in biofilms has been plagued for many years. Free TCS has shown to be effective against planktonic bacteria, but not those in the biofilm mode. Although the encapsulated TCS showed reduced antibacterial activity against planktonic bacteria, the advantages with respect to biofilm eradication became evident especially under $\mathrm{pH}$ 5.5. $\mathrm{M}_{\mathrm{L}-\mathrm{E}-\mathrm{A}} / \mathrm{TCS}$ could efficiently penetrate and accumulate in the biofilm to reach and kill the bacteria inside of the biofilm at acidic conditions. This could be due to that, upon the initial penetration, the $\mathrm{pH}$-sensitive PAE segments of $\mathrm{M}_{\mathrm{L}-\mathrm{E}-\mathrm{A}}$ efficiently switched to be positively charged and rose to the surface, which could effectively engage the interaction with the negatively charged bacteria in the biofilms [25, 33-35]. Subsequently, by close contact with the bacteria, $\mathrm{M}_{\mathrm{L}-\mathrm{E}-\mathrm{A}}$ was able to be degraded by lipase, leading to a quick release of the loaded antimicrobial drug [36]. As an overall result, the antibacterial effect of micelles could be partially enhanced by promoting micelles-bacterium interactions at acidic $\mathrm{pH}$, further demonstrating the delivery system based on $\mathrm{M}_{\mathrm{L}-\mathrm{E}-\mathrm{A}}$ has great potential in the treatment of infections with localized acidity. 


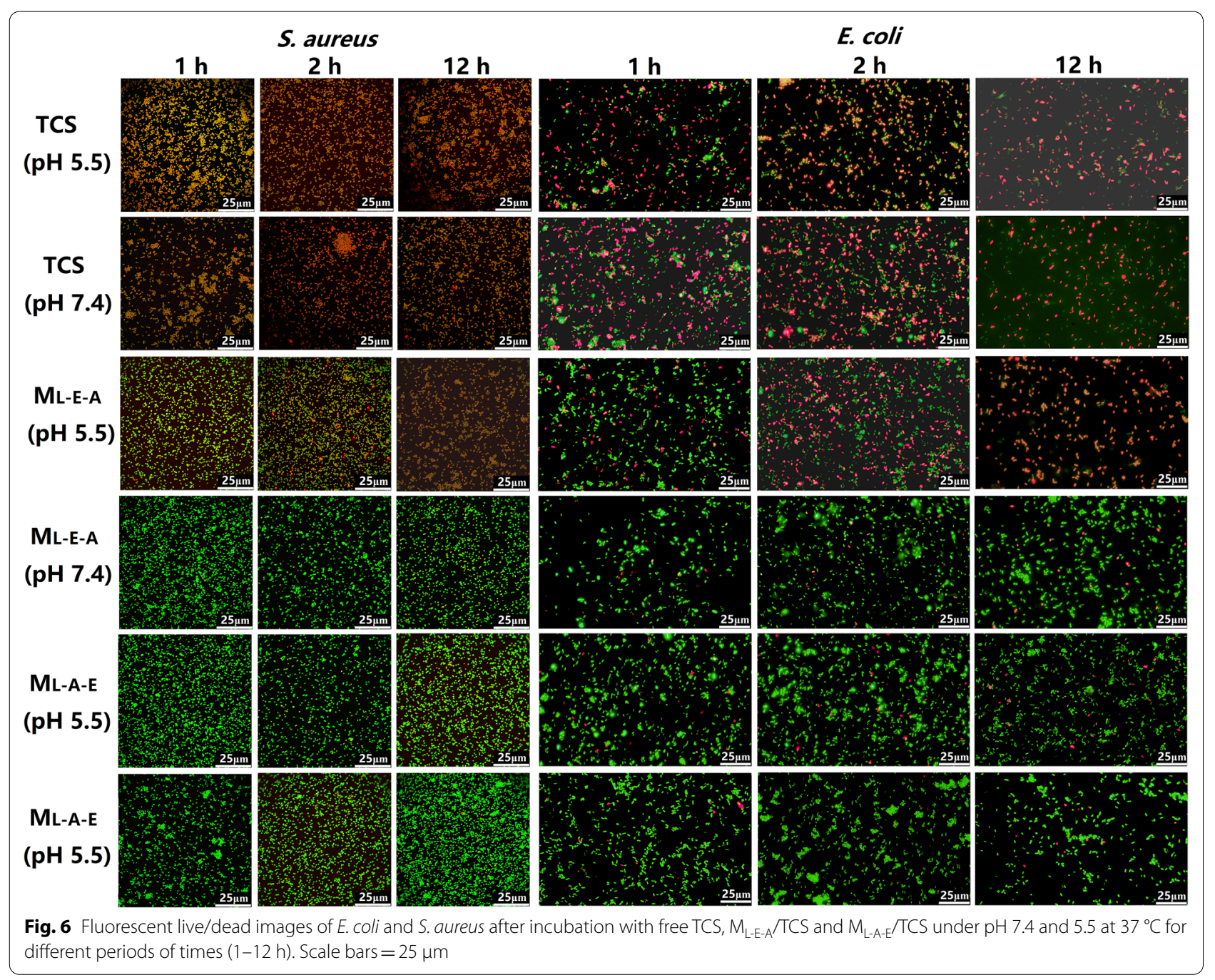

\section{In vivo anti-biofilm effects on catheters}

Implant-related infection has been associated with bacterial colonization and biofilm formation during artificial implants [37]. In this section, the in vivo eradication effects of free TCS and TCS-loaded micelles on the subcutaneously implanted catheters covered with E. coli biofilms were investigated in vivo. The catheters showed no signs of contamination and color changes after 5 days of $\mathrm{M}_{\mathrm{L}-\mathrm{E}-\mathrm{A}} / \mathrm{TCS}$ treatment (Fig. 8A). SEM observation also indicated that there was no obvious biofilm on the surface of catheters. The established biofilm on catheters could be significantly disrupted and the embedded aggregated bacteria could be eradicated by $\mathrm{M}_{\mathrm{L}-\mathrm{E}-\mathrm{A}} / \mathrm{TCS}$ treatment (Fig. 8B). By contrast, the catheter surface was greatly contaminated with bacteria, and biofilms were apparently covered after the saline treatment. Although the treatment by $\mathrm{M}_{\mathrm{L}-\mathrm{A}-\mathrm{E}} / \mathrm{TCS}$ and free TCS could alleviate the contamination levels on the catheters, the biofilms could not be eradicated completely. Moreover, a remarkable reduction of tissue lesions (Fig. 8C), decreased CFU (Fig. 8D) and recovered body weight (Fig. 8E) further confirmed the inflammatory disappearance after treatment with $\mathrm{M}_{\mathrm{L}-\mathrm{E}-\mathrm{A}} / \mathrm{TCS}$ in comparation with free TCS and $\mathrm{M}_{\mathrm{L}-\mathrm{A}-\mathrm{E}} / \mathrm{TCS}$. The symptoms of serious infection, including local redness and swelling, weight loss, anorexia and fever, could not be observed in $\mathrm{M}_{\mathrm{L}-\mathrm{E}-\mathrm{A}} /$ TCS group.

No significant in vitro cytotoxicity (Additional file 1: Fig. S8A) and hemolytic behavior (Additional file 1: Fig. S8B) was observed for both $\mathrm{M}_{\mathrm{L}-\mathrm{E}-\mathrm{A}} / \mathrm{TCS}$ and $\mathrm{M}_{\mathrm{L}-\mathrm{A}-\mathrm{E}} /$ TCS. Moreover, the H\&E staining images of heart, liver, spleen, lung and kidney (Fig. 9) suggested that no obvious lesions or damage were observed in those tissues in both TCS-loaded micelles treated group, suggesting good biocompatibility. Conversely, free TCS caused fatty degeneration of hepatocytes, which was consistent with previous study. [38] Encapsulation of TCS in micelles could significantly lower its hepatotoxicity. 


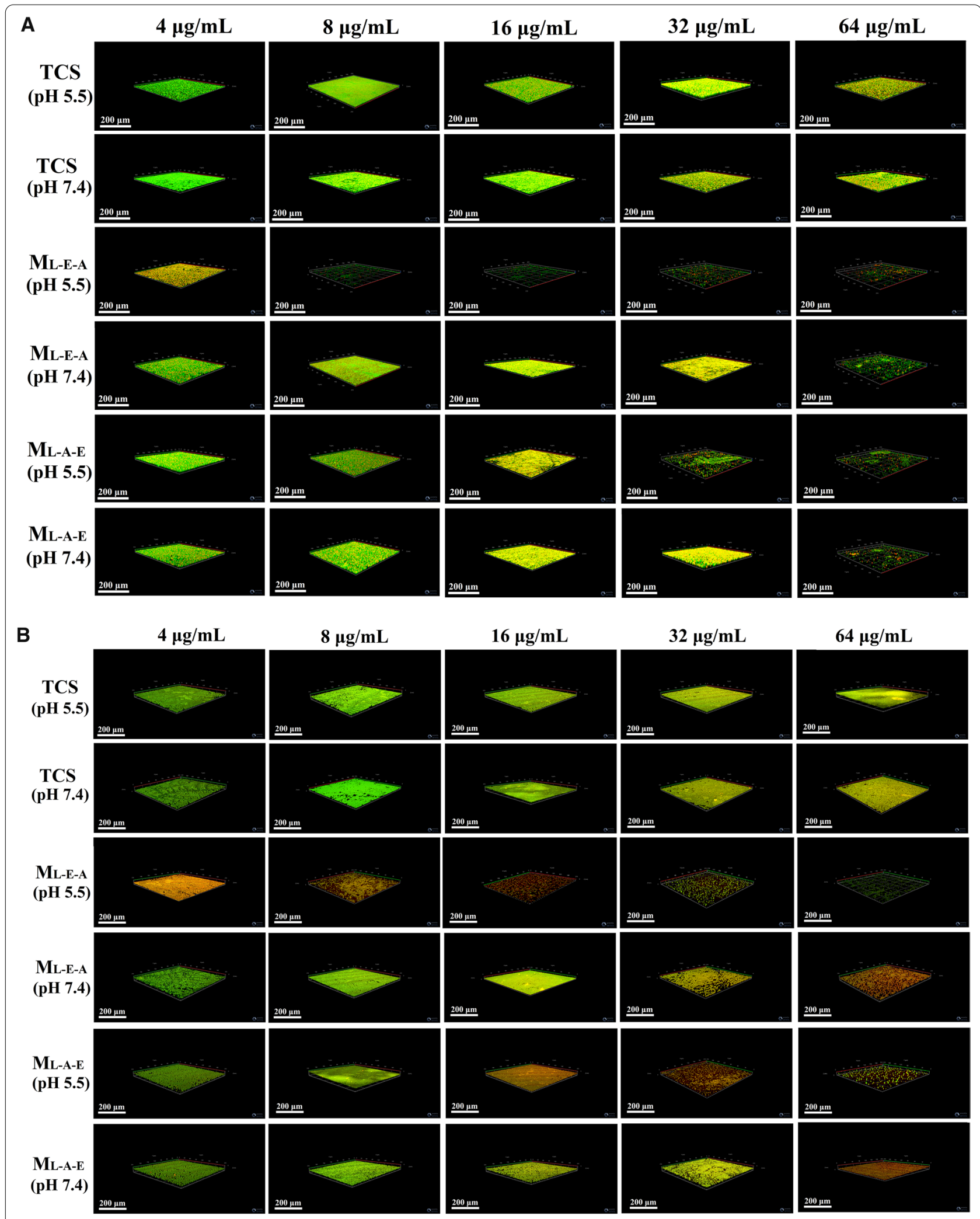

Fig. 7 CLSM analysis of S. aureus (A) and E. coli (B) biofilm eradication. The S. aureus and E. coli biofilms were treated with free TCS, M $\mathrm{L}_{\mathrm{LE}-\mathrm{A}} / \mathrm{TCS}$ and $\mathrm{M}_{\mathrm{L}-\mathrm{A}-\mathrm{E}} / \mathrm{TCS}$ at different concentrations overnight 


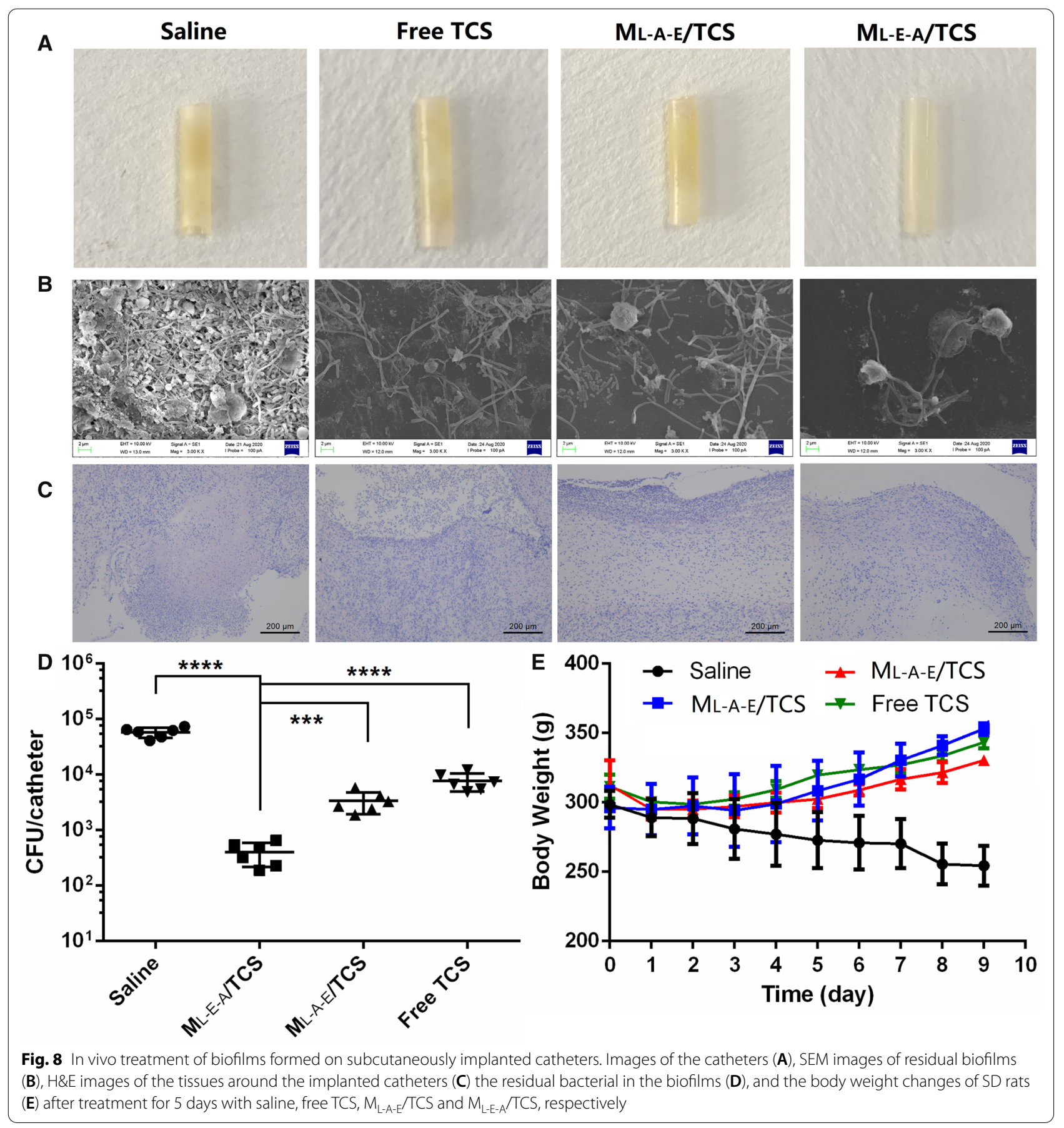

These finding indicated that treatment of implantrelated infection with $\mathrm{M}_{\mathrm{L}-\mathrm{E}-\mathrm{A}} / \mathrm{TCS}$ could suppress bacterial growth, eradicate biofilms, lower the degree of infection with negligible side effects.

\section{Conclusions}

Due to the increase of persistent bacterial infection, new enhanced strategies are urgently needed. In this study, we applied three types of $\mathrm{pH}$-sensitive copolymers, 


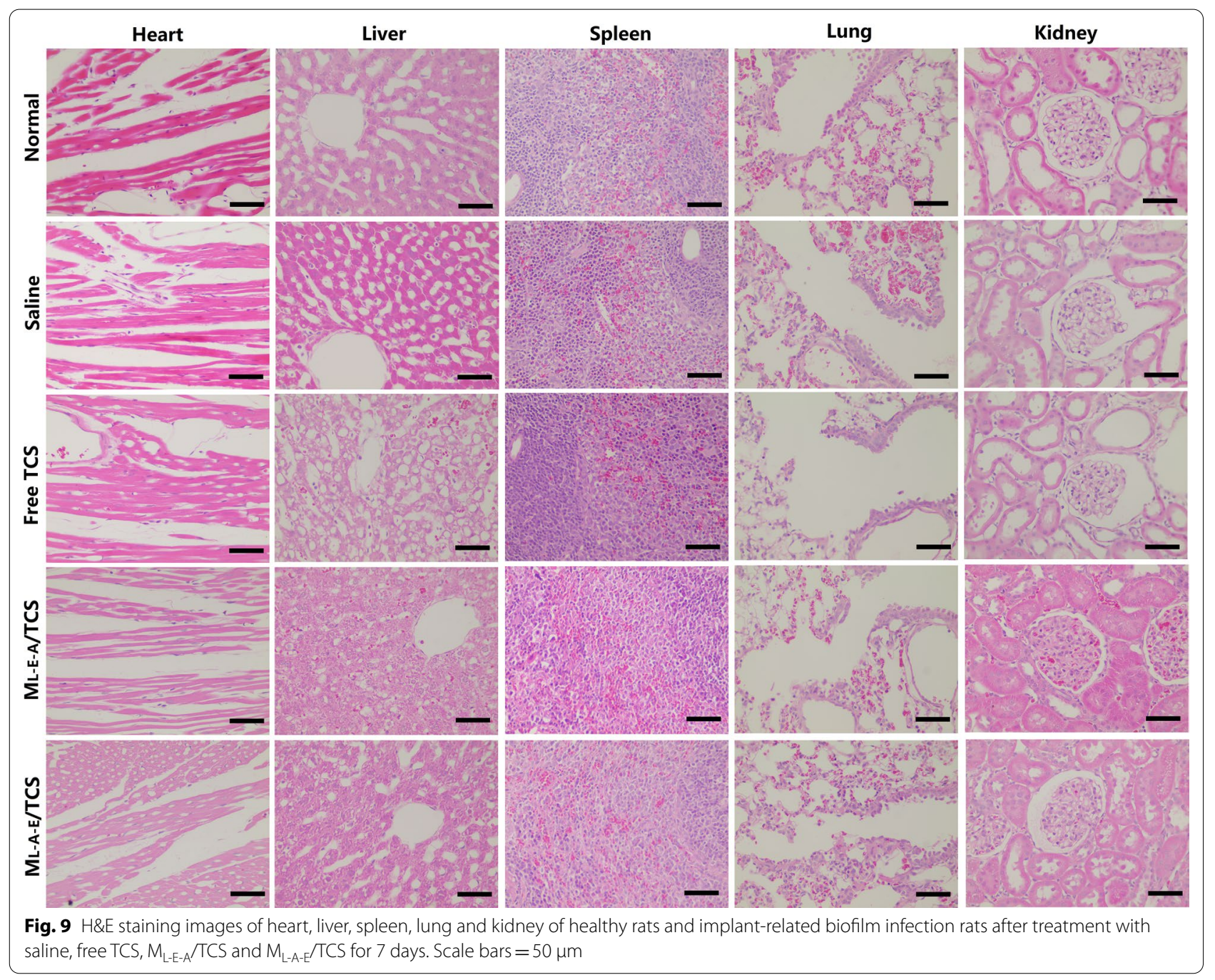

PLA-PAE-mPEG, PAE-PLA-mPEG and PLA-PEG-PAE, which could self-assemble into three $\mathrm{pH}$-sensitive surface charge-adaptive micelles $\left(\mathrm{M}_{\mathrm{L}-\mathrm{A}-\mathrm{E}}, \mathrm{M}_{\mathrm{A}-\mathrm{L}-\mathrm{E}}\right.$ and $\left.\mathrm{M}_{\mathrm{L}-\mathrm{E}-\mathrm{A}}\right)$ against biofilm-related infection, and focused on their structure-function relationship. Compared with $\mathrm{M}_{\mathrm{L}-\mathrm{A}-\mathrm{E}}$ and $\mathrm{M}_{\mathrm{A}-\mathrm{L}-\mathrm{E}}, \mathrm{M}_{\mathrm{L}-\mathrm{E}-\mathrm{A}}$ showed superior capabilities in switching surface charge, binding to bacteria, penetrating biofilms, killing bacteria in deeper layers of a biofilm in vitro, and more efficiency in curing biofilm-related infection in vivo. In summary, the study indicated that rational design the architecture of $\mathrm{pH}$-sensitive copolymers to maximize the charge-switching capability need to be considered when they were constructed for biofilm treatment. Due to the stealth performance and potential surface adaptive ability of the $\mathrm{M}_{\mathrm{L}-\mathrm{E}-\mathrm{A}}$, the resistance of biofilms could be bypassed, thereby providing a potentially effective strategy against EPS-producing bacteria in its biofilm form.

\section{Supplementary Information}

The online version contains supplementary material available at https://doi. org/10.1186/s12951-021-00980-8.

Additional file 1: Fig. S1 Detailed synthetic route of $P L A_{5 K}-P E G_{5 K}-P A E_{5 K}$. Fig. S2 Detailed synthetic route of $P L A_{5 K}-P A E_{5 K}-m P E G_{5 K}$. Fig. S3 Detailed synthetic route of $P A E_{5 K}-P L A_{5 K}-m P E G_{5 K}$. Fig. $\mathbf{S}{ }^{1} H$ NMR spectrum of $P L A_{5 K}-P E G_{5 K}-P A E_{5 K}$. Fig. $\mathbf{S 5}{ }^{1} H$ NMR spectrum of $P L A_{5 K}-P A E_{5 K}-m P E G_{5 K}$ Fig. $\mathbf{S} \mathbf{}^{1} \mathrm{H}$ NMR spectrum of $P A E_{5 K}-P L A_{5 K}-M P E G_{5 K}$. Fig. $\mathbf{S 7}$ The typical GPC spectrum of PAE ${ }_{5 K}-P L A_{5 K}-m P E G_{5 K}, P L A_{5 K}-P^{-} G_{5 K}-P^{\prime} E_{5 K}$ and $P L A_{5 K}-P A E_{5 K}-m P E G_{5 K}$. Fig. S8 The in vitro cytotoxicity (A) and hemolysis behavior (B) of $\mathrm{M}_{\mathrm{LEE}-\mathrm{A}} / \mathrm{TCS}$ and $\mathrm{M}_{\mathrm{L}-\mathrm{A}-\mathrm{E}} / \mathrm{TCS}$ as a function of TCS concentration (mean $\pm S D, n=6$ ). Table $\mathbf{S} 1$ The characteristic of synthesized copolymers.

\section{Acknowledgements}

Not applicable.

\section{Authors' contributions}

RG and KL performed the experiments and analysed the data; $B T$ and $C W$ analysed the data; $\mathrm{XC}, \mathrm{XJ}$ and $\mathrm{HH}$ performed the in vivo experiments; $\mathrm{WH}$ 
designed and performed the experiments, analysed the data, and wrote the paper. All authors read and approved the final manuscript.

\section{Funding}

This study was financially supported by the Taishan Scholar Project of Shandong Province (No. tsqn201909143) and Key Program of Natural Science Foundation of Shandong Province (No. ZR2020KE015).

\section{Availability of data and materials}

All data generated or analysed during this study are included in this published article.

\section{Declarations}

\section{Ethics approval and consent to participate}

The SD rats were obtained from Pengyue Laboratory Animal Breeding Co., Ltd (Jinan, Shandong, China) and the animal studies were conducted according to the experimental protocols by Institutional Animal Care and Use Committee of Binzhou Medical University.

\section{Consent for publication}

All authors read and approved the final manuscript for publication.

\section{Competing interests}

This work was not financially and inappropriately influenced by any other professional or other personal interests.

Received: 2 April 2021 Accepted: 27 July 2021

Published online: 06 August 2021

\section{References}

1. Lewis K. Persister cells, dormancy and infectious disease. Nat Rev Microbiol. 2007;5(1):48-56.

2. Romling U, Balsalobre C. Biofilm infections, their resilience to therapy and innovative treatment strategies. J Intern Med. 2012;272(6):541-61.

3. Costerton JW, Stewart PS, Greenberg EP. Bacterial biofilms: a common cause of persistent infections. Science. 1999;284(5418):1318-22.

4. Fux CA, Costerton JW, Stewart PS, Stoodley P. Survival strategies of infectious biofilms. Trends Microbiol. 2005;13(1):34-40.

5. Flemming $\mathrm{HC}$, Wingender J. The biofilm matrix. Nat Rev Microbiol. 2010;8(9):623-33.

6. Beloin C, Renard S, Ghigo JM, Lebeaux D. Novel approaches to combat bacterial biofilms. Curr Opin Pharmacol. 2014;18:61-8.

7. Baker P, Hill PJ, Snarr BD, Alnabelseya N, Pestrak MJ, Lee MJ, Jennings LK, Tam J, Melnyk RA, Parsek MR, Sheppard DC, Wozniak DJ, Howell PL. Exopolysaccharide biosynthetic glycoside hydrolases can be utilized to disrupt and prevent Pseudomonas aeruginosa biofilms. Sci Adv. 2016;2(5):e1501632

8. Hu D, Li H, Wang B, Ye Z, Lei W, Jia F, Jin Q, Ren KF, Ji J. Surface-adaptive gold nanoparticles with effective adherence and enhanced photothermal ablation of methicillin-resistant Staphylococcus aureus biofilm. ACS Nano. 2017;11(9):9330-9.

9. Liu Y, Ren Y, Li Y, Su L, Zhang Y, Huang F, Liu J, Liu J, van Kooten TG, An Y, Shi L, van der Mei HC, Busscher HJ. Nanocarriers with conjugated antimicrobials to eradicate pathogenic biofilms evaluated in murine in vivo and human ex vivo infection models. Acta Biomater. 2018;79:331-43.

10. Tian S, Su L, Liu Y, Cao J, Yang G, Ren Y, Huang F, Liu J, An Y, van der Mei HC, Busscher HJ, Shi L. Self-targeting, zwitterionic micellar dispersants enhance antibiotic killing of infectious biofilms - an intravital imaging study in mice. Sci Adv. 2020;6(33):eabb1112.

11. Liu Y, Mei HCVD, Zhao B, Zhai Y, Cheng T, Li Y, Zhang Z, Busscher HJ, Ren Y, Shi L. Eradication of multidrug-resistant staphylococcal infections by light-activatable micellar nanocarriers in a murine model. Adv Funct Mater. 2017;27:1701974.

12. Gref R, Minamitake Y, Peracchia MT, Trubetskoy V, Torchilin V, Langer R. Biodegradable long-circulating polymeric nanospheres. Science. 1994;263(5153):1600-3.
13. Lin $M H$, Hung CF, Aljuffali IA, Sung CT, Huang CT, Fang JY. Cationic amphiphile in phospholipid bilayer or oil-water interface of nanocarriers affects planktonic and biofilm bacteria killing. Nanomedicine. 2017;13(2):353-61.

14. Mamusa M, Sitia L, Barbero F, Ruyra A, Calvo TD, Montis C, GonzalezParedes A, Wheeler GN, Morris CJ, McArthur M, Berti D. Cationic liposomal vectors incorporating a bolaamphiphile for oligonucleotide antimicrobials. Biochim Biophys Acta Biomembr. 2017;1859(10):1767-77.

15. Ng VW, Ke X, Lee AL, Hedrick JL, Yang YY. Synergistic co-delivery of membrane-disrupting polymers with commercial antibiotics against highly opportunistic bacteria. Adv Mater. 2013;25(46):6730-6.

16. Wang J, Byrne JD, Napier ME, DeSimone JM. More effective nanomedicines through particle design. Small. 2011;7(14):1919-31.

17. Hama S, Itakura S, Nakai M, Nakayama K, Morimoto S, Suzuki S, Kogure K. Overcoming the polyethylene glycol dilemma via pathological environment-sensitive change of the surface property of nanoparticles for cellular entry. J Control Release. 2015;206:67-74.

18. Gao Y, Wang J, Chai M, Li X, Deng Y, Jin Q, Ji J. Size and charge adaptive clustered nanoparticles targeting the biofilm microenvironment for chronic lung infection management. ACS Nano. 2020;14(5):5686-99.

19. Davies DG, Marques CN. A fatty acid messenger is responsible for inducing dispersion in microbial biofilms. J Bacteriol. 2009;191(5):1393-403.

20. Simmen HP, Blaser J. Analysis of $\mathrm{pH}$ and $\mathrm{pO}_{2}$ in abscesses, peritoneal fluid, and drainage fluid in the presence or absence of bacterial infection during and after abdominal surgery. Am J Surg. 1993;166(1):24-7.

21. Mura S, Nicolas J, Couvreur P. Stimuli-responsive nanocarriers for drug delivery. Nat Mater. 2013;12(11):991-1003.

22. Hu J, Zhang G, Liu S. Enzyme-responsive polymeric assemblies, nanoparticles and hydrogels. Chem Soc Rev. 2012;41 (18):5933-49.

23. Li LL, Xu JH, Qi GB, Zhao X, Yu F, Wang H. Core-shell supramolecular gelatin nanoparticles for adaptive and "on-demand" antibiotic delivery. ACS Nano. 2014:8(5):4975-83.

24. Liu Y, Busscher HJ, Zhao B, Li Y, Zhang Z, van der Mei HC, Ren Y, Shi L. Surface-adaptive, antimicrobially loaded, micellar nanocarriers with enhanced penetration and killing efficiency in Staphylococcal biofilms. ACS Nano. 2016;10(4):4779-89.

25. Radovic-Moreno AF, Lu TK, Puscasu VA, Yoon CJ, Langer R, Farokhzad OC. Surface charge-switching polymeric nanoparticles for bacterial cell walltargeted delivery of antibiotics. ACS Nano. 2012;6(5):4279-87.

26. Hong W, Chen D, Zhang X, Zeng J, Hu H, Zhao X, Qiao M. Reversing multidrug resistance by intracellular delivery of Pluronic(R) P85 unimers. Biomaterials. 2013;34(37):9602-14.

27. Ma QQ, Dong N, Shan AS, Lv YF, Li YZ, Chen ZH, Cheng BJ, Li ZY. Biochemical property and membrane-peptide interactions of de novo antimicrobial peptides designed by helix-forming units. Amino Acids. 2012;43(6):2527-36

28. Dong N, Ma Q, Shan A, Lv Y, Hu W, Gu Y, Li Y. Strand length-dependent antimicrobial activity and membrane-active mechanism of arginine- and valine-rich beta-hairpin-like antimicrobial peptides. Antimicrob Agents Chemother. 2012;56(6):2994-3003.

29. Chintakunta R, Buaron N, Kahn N, Moriah A, Lifshiz R, Goldbart R, Traitel T, Tyler B, Brem H, Kost J. Synthesis, characterization, and self-assembly with plasmid DNA of a quaternary ammonium derivative of pectic galactan and its fluorescent labeling for bioimaging applications. Carbohydr Polym. 2016;150:308-18.

30. Lynn DM, Amiji MM, Langer R. pH-responsive polymer microspheres: rapid release of encapsulated material within the range of intracellular pH. Angew Chem Int Ed Engl. 2001;40(9):1707-10.

31. Gao GH, Im GH, Kim MS, Lee JW, Yang J, Jeon H, Lee JH, Lee DS. Magnetite-nanoparticle-encapsulated $\mathrm{pH}$-responsive polymeric micelle as an MRI probe for detecting acidic pathologic areas. Small. 2010;6(11):1201-4

32. Liu D, Liu F, Song YK. Recognition and clearance of liposomes containing phosphatidylserine are mediated by serum opsonin. Biochim Biophys Acta. 1995;1235(1):140-6.

33. Chen M, Wei J, Xie S, Tao X, Zhang Z, Ran P, Li X. Bacterial biofilm destruction by size/surface charge-adaptive micelles. Nanoscale. 2019:11(3):1410-22.

34. Tseng BS, Zhang W, Harrison JJ, Quach TP, Song JL, Penterman J, Singh PK, Chopp DL, Packman Al, Parsek MR. The extracellular matrix protects Pseudomonas aeruginosa biofilms by limiting the penetration of tobramycin. Environ Microbiol. 2013;15(10):2865-78. 
35. Chen M, Xie S, Wei J, Song X, Ding Z, Li X. Antibacterial micelles with vancomycin-mediated targeting and $\mathrm{pH} /$ /ipase-triggered release of antibiotics. ACS Appl Mater Interfaces. 2018;10(43):36814-23.

36. Xiong MH, Bao Y, Yang XZ, Wang YC, Sun B, Wang J. Lipase-sensitive polymeric triple-layered nanogel for "on-demand" drug delivery. J Am Chem Soc. 2012;134(9):4355-62.

37. Azzopardi EA, Ferguson EL, Thomas DW. The enhanced permeability retention effect: a new paradigm for drug targeting in infection. J Antimicrob Chemother. 2013;68(2):257-74.
38. Yueh MF, Taniguchi K, Chen S, Evans RM, Hammock BD, Karin M, Tukey $\mathrm{RH}$. The commonly used antimicrobial additive triclosan is a liver tumor promoter. Proc Natl Acad Sci USA. 2014;111(48):17200-5.

\section{Publisher's Note}

Springer Nature remains neutral with regard to jurisdictional claims in published maps and institutional affiliations.
Ready to submit your research? Choose BMC and benefit from:

- fast, convenient online submission

- thorough peer review by experienced researchers in your field

- rapid publication on acceptance

- support for research data, including large and complex data types

- gold Open Access which fosters wider collaboration and increased citations

- maximum visibility for your research: over 100M website views per year

At BMC, research is always in progress.

Learn more biomedcentral.com/submissions 